\title{
UPSTREAM AND DOWNSTREAM MIGRATIONS IN RELATION TO THE REPRODUCTIVE CYCLE AND TO ENVIRONMENTAL FACTORS IN THE AMPHIPOD, GAMMARUS ZADDACHI
}

\author{
by \\ H. G. DENNERT, A. L. DENNERT, P. KANT, S. PINKSTER \& \\ J. H. STOCK (coordinating editor) \\ Zoölogisch Museum, University of Amsterdam and Laboratoire Ch. Maurice de la Faculté libre \\ des Sciences de Lille
}

\begin{abstract}
SUMMARY
1. The real identity has been studied of juvenile gammarids, that were found in the fresh-water tidal region of the River Slack (France), 3 to $4 \mathrm{~km}$ inland of the mouth of its estuary. At the outset, these juveniles were (on basis of their morphology) considered to belong to Gammarus salinus.

2. Rearing demonstrated that the juveniles in question developed into adult Gammarus zaddachi. This indicates that the morphological criteria used in discriminating between G. salinus and G. zaddachi fail in juvenile material. Several morphological criteria are discussed and tested. It appears that a $100 \%$ certain key character does not exist, meaning that it is not possible to identify with absolute certainty all individuals in mixed populations of the two species.
\end{abstract}

3. At the same time, the resemblance of juvenile G. zaddachi to adult $G$. salinus provides us with a morphological feature allowing rapid distinction between adult and juvenile G. zaddachi in studies with large numbers of individuals.

4. In studies of the reproduction and migration of G. zaddachi, several types of nets were developed, both for anadromous and catadromous migrants. These nets agreed with one another in having the same catch capacity.

5. The activity of $G$. zaddachi shows a diurnal periodicity, the activity peak falling at night.

This behavior results in a down-river migration ("drift"), which reaches its maximum 2 to 3 hours after sunset, slowing down later in the night, until the drift virtually stops at sunrise. No influence of the light intensity during the night (moon phase, clouds) was found.

6. During the periods with H.W.S., the direction of the stream reverses in the entire study area. In the parts of the river adjacent to the estuary, this stream reversal is accompanied by a rapid increase in salinity. In the more up-river reaches, no salinity changes occur, so that we find there a fresh-water tidal region.

7. All year round a certain part of the population of G. zaddachi living at a given place (the so-called standing crop) migrates down-river. During the autumn equinoxal spring-tides (and - though much less - during the spring equinox) mass migration takes place in up-river direction. This up-river migration takes place only at nights in which the stream reverses under the influence of the H.W.S. Practically exclusively juvenile animals participate in the up-river migration.
8. Per night, the maximum number of animals caught per net $(=30 \times 50 \mathrm{~cm})$ was 1,500 downstreamers and 6,000 upstreamers of $G$. zaddachi, which may roughly correspond with 30,000 downstreamers and 120,000 upstreamers per given section of the river. No other gammarid species in the river Slack shows migratory behavior.

9. Tagging experiments showed, that animals migrating up-river cover distances of 40 to $60 \mathrm{~m}$ per night. Downriver migrants cover at least $50 \mathrm{~m}$ and at most $80 \mathrm{~m}$ per night.

10. Several indications make it plausible that, though G. zaddachi uses the water currents for its migration, the up-river and down-river movements are not merely accidental transportation. Animals in the (physiological) phase of moving down-river continue to do so, irrespective of the direction of the stream. The same holds true for animals in the phase of moving in up-river direction.

11. The reproductive cycle of $G$. zaddachi is completed in one year. The young appear in spring, in autumn these juveniles grow adult, the first ovigerous females appear in December, the maximum production of eggs falls in the early spring. All adults die after the reproduction period.

12. The reproductive cycle is coupled with the migration cycle. The females participating in down-river migration can, dependent on temperature and salinity, successfully produce an offspring. At temperatures above $7^{\circ} 5 \mathrm{C}$ this happens only in the mixohaline parts of the river Slack. When the temperature drops below $7^{\circ} 5 \mathrm{C}$, egg production is also possible in the limnic reaches of the river. The juveniles pass the summer in the estuarine region. In this season an important portion of the up-river distribution area of G. zaddachi is depopulated. Repopulation of the limnic region by juveniles takes place in the fall, aided by the reversed water currents at H.W.S., thus completing the cycle.

\section{INTRODUCTION}

Downstream movements, often called "organic drift", are known for various benthic aquatic invertebrates, especially insects (Dendy, 1944; Müller, 1954a; Tanaka, 1960; Elliot, 1967; McLay, 1968), but also for gammarids (Waters, 1962a; Müller, 1963a, 1963b; Minckley, 1964; Lehmann, 1967). Various explanations have been given for this phenomenon (ably summarized by Lehmann, 1967), such as: 
(1) Accidental transport. This is particularly plausible for hatching insect larvae, that are transported ("drifted") more or less at random to the lower reaches of a brook or river, where the imagines hatch. The adult females then fly upstream for the ovoposition, thus completing the "Besiedlungskreislauf" ("settlement cycle", Müller, 1954b).

For a gammarid, whose entire life-cycle is completed in the water, the "fly back" possibility is excluded, of course.

(2) The drift rate corresponds with the reproductive rate. Waters (1961, 1964, 1965) showed this to be the case in various American limnic invertebrates, including Gammarus limnaeus Smith. The drift is considered in these cases as a compensatory mechanism preventing overpopulation.

(3) The drift rate is correlated with the stage of development and not with the population density (Müller, 1966b).

(4) The (downstream) drift is compensated by up- stream migrations. Such catadromous movements have been demonstrated at various occasions: for Gammarus bousfieldi Cole \& Minckley by Minckley, 1964; for G.pulex (Linnaeus) by Müller, 1966a, and by Hultin, 1968; for G.fossarum Koch by Lehmann, 1967.

In our experiments with G.zaddachi Sexton, a complex relation of the upstream and downstream movements. with the life-cycle (point 3 ) and with various environmental factors (light intensity, salinity, temperature) has been demonstrated. We have found no indications that the drift is merely a compensation for overpopulation of the upstream reaches. Our results contradict the supposition of accidental transport.

It must be remarked that the four Gammarus species used in the experiments by other authors, cited above, are all exclusively limnic, whereas $G$. $z a d d a c h i$ is a strongly euryhaline species, ranging from practically fresh to almost marine waters $(0.04$ 18.5\% $\%$ Cl, cf. Stock, Nijssen \& Kant, 1966).

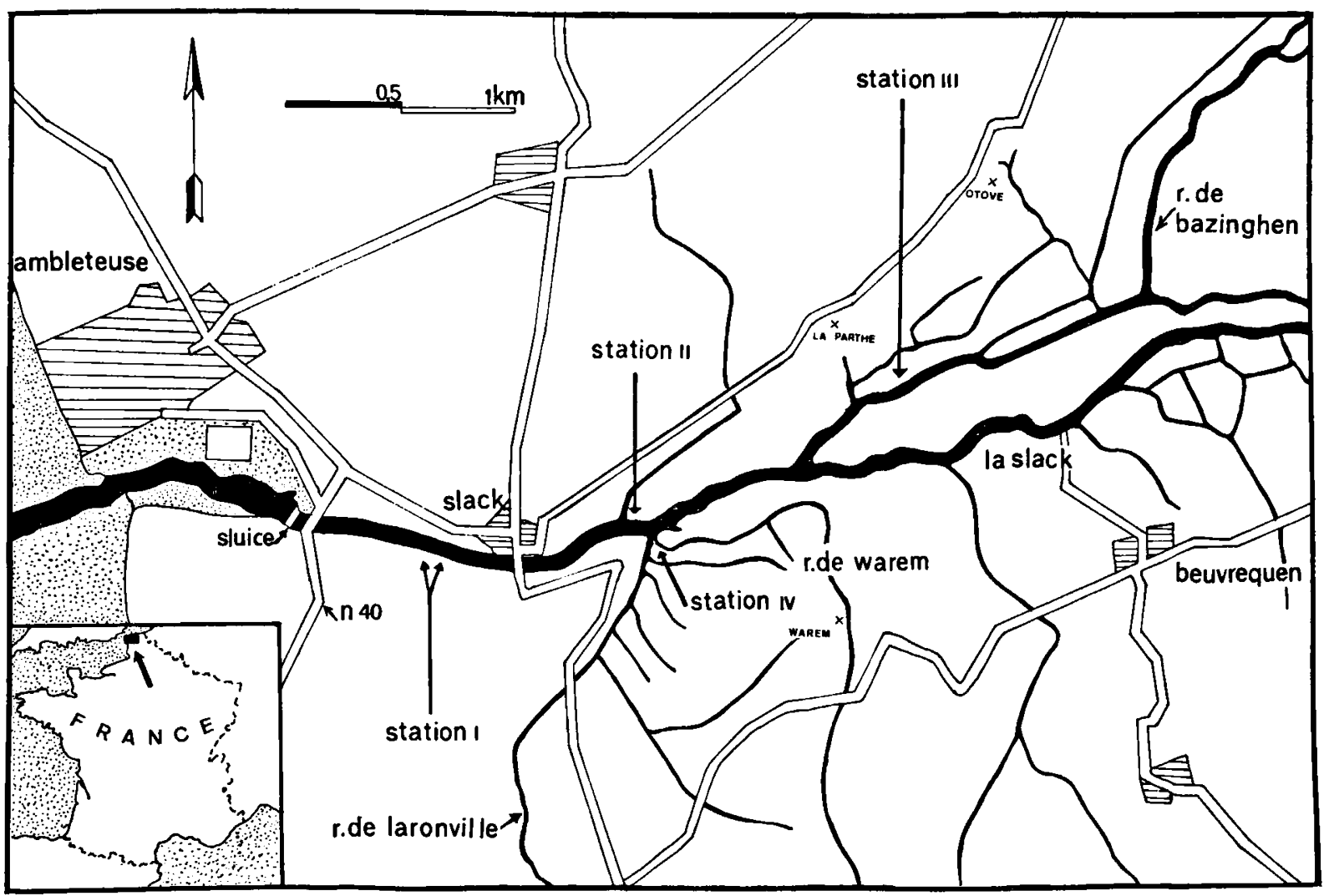

Fig. 1. The seaward part of the stream system of the river Slack. In this part of the river Gammarus zaddachi is found $(x=$ farm houses). 


\section{STUDY AREA AND ENVIRONMENT}

Our investigations were carried out from May 1966 to August 1968 in the river Slack, a stream running practically from East to West in the northwestern part of France (département Pas-de-Calais). It runs chiefly through a calcareous region and debouches into the Straits of Dover just south of the village of Ambleteuse. Feeded by springs, but principally by the rain, neither the course of the river, nor its water composition have been subject to great human influences. In a direct line, the distance between the main spring of the river and the sea is $17.5 \mathrm{~km}$. In this riversystem 15 species of Amphipoda belonging to the family Gammaridae have been found (Stock et al., 1966); of these, Gammarus zaddachi occupies a stretch of the river of some $4200 \mathrm{~m}$ length, which is practically fresh in its most upstream portion (chlorinity $0.04-0.10 \%$ ), mixohaline in the greater part, to almost marine at its most downstream end (chlorinity $18.5 \%$ at high tide).

The part of the river Slack and its estuary in which G.zaddachi occurs is illustrated in fig. 1. The tides can enter freely into the wide estuarine part of the river, west of highroad $\mathrm{N} 40$. The estuary is bordered there by intertidal flats and salt marshes. The tides are rather considerable, the tidal differences being 8 to 9 meters at equinoxal spring tides, and 5 meters at normal neap tides. The wide estuary is separated by a small sluice, in highroad $N 40$, from the narrower river bed. This sluice is of an automatic type, consisting of an excentrically suspended door that opens on the force of the river drain, and that closes on the force of the incoming tides. Since the sluice's performances are rather poor, tidal influence is perceptible quite a distance upstream of the sluice. In fact the entire stretch of the Slack inhabited by G.zaddachi is influenced by the tides, either through a rise in salinity (which is noticeable as far upstream as the confluence of the Slack and the Ruisseau de Laronville at the place marked "Station II" in fig. 1, where the chorinity at $\mathrm{H} \mathrm{H} \mathrm{W} \mathrm{S}$ rises to $0.1 \%$ ), or through a kind of fresh-water tides, upstream of Station II. During high tide in the estuary, the normal flow of the river is obstructed, the water rises, and - especially during spring tides the direction of the current (which is normally toward the sea), reverses, so that the water flows inland for a short period (cf. fig. 15).

During the observation period, the surface temperature of the water in the river Slack varied between $18.6^{\circ} \mathrm{C}$ (Aug. 5, 1967) and $3.5^{\circ} \mathrm{C}$ (Feb. 27, 1968). Table XII summarizes temperature measurements in
Table I. Current speed in $\mathrm{cm} / \mathrm{sec}$. in the River Slack at Station I on 5 August 1967.

Positive figures indicate currents in seaward direction, negative figures indicate inland currents. Tidal difference $37 \mathrm{~cm}$.

\begin{tabular}{|c|c|c|}
\hline local time & speed & remarks \\
\hline 11.40 & -10 & high tide in open sea \\
\hline 12.15 & 0 & highest water level at Station I \\
\hline 12.30 & +20 & temp. $17.1^{\circ} \mathrm{C}$ \\
\hline 13.30 & +53 & temp. $17.6^{\circ} \mathrm{C}$. \\
\hline 14.30 & +41 & temp. $17.8^{\circ} \mathrm{C}$. \\
\hline 15.30 & +43 & temp. $18.1^{\circ} \mathrm{C}$ \\
\hline 16.30 & +40 & temp. $18.5^{\circ} \mathrm{C}$. \\
\hline 17.30 & +40 & temp. $18.6^{\circ} \mathrm{C}$ \\
\hline 18.30 & +39 & $\begin{array}{r}18.6^{\circ} \mathrm{C} ., \text { lowest water } \\
\text { level at Station I }\end{array}$ \\
\hline 18.49 & +37 & $\begin{array}{l}\text { temp. } 18.5^{\circ} \mathrm{C} ., \text { low tide in } \\
\text { open sea }\end{array}$ \\
\hline 19.00 & +40 &.-- \\
\hline
\end{tabular}

the observation period. Admittedly, these measurements are rather incidental, but they nevertheless clearly give a rough picture of the yearly temperature cycle in the area. However, we are convinced that higher and lower temperatures are not infrequent in the area, when observed over a longer period.

For further details concerning the topography of the Slack and the distribution of the various species of gammarids, the reader is referred to the publication of Stock et al., 1966.

In the area occupied by G.zaddachi, four fixed sampling stations have been chosen (stations I to IV in fig. 1). In Station I, tidal influence is still strong, and reflected by both a sharp and strong rise in salinity at high tide, and a reversal of the direction of the current.

In Station II, the current reverses at high tide, but only a slight rise in chlorinity (rising from the normal river value of $0.03-0.06 \%$ to $0.1 \%$ ) occurs at springtides only.

Station III is situated in a tributary of the Slack, called Rivière de Bazinghen; here, the current still reverses (one can speak of a kind of fresh-water tidal wave), but the water stays fresh all the time.

At Stations I to III, the rivers are confined to a rather narrow bed with steep banks, being about 5 to $6 \mathrm{~m}$ wide, and being $40 \mathrm{~cm}$ (in the dry season at low tide) to $160 \mathrm{~cm}$ (at the wet season at high tide) deep.

Station IV finally is situated near the mouth of a small brook, the Ruisseau de Warem, where this debouches into a slightly larger rivulet, the Ruisseau 
de Laronville, which in turn is an affluent of the Slack. From the mouth of the Ruisseau de Warem to the bed of the river Slack, there is a distance of $28 \mathrm{~m}$ only. At Station IV, the brook is about $40 \mathrm{~cm}$ wide and 10 tot $20 \mathrm{~cm}$ deep.

Most localities mentioned in this article can be found in fig. 1. More information gives the Carte de France 1/50000, feuille XXI-3, Marquise, edited by the Institut Géographique National, Paris (édition 1963).

\section{METHODS}

\section{1) Nets}

Conical nets, with a rectangular aperture of $30 \times$ $50 \mathrm{~cm}$ in several variations were used. In every instance, the conical net could be fixed with poles or with wire at every desired place and at every depth in the river. At the end of the net, a rapidly changeahle bag was fixed by a screw clip on a piece of hard plastic tubing. The type illustrated in fig. 2 was used for downstream drifting animals. For upstream moving animals, the same net was used, but instead of a simple bag at the end, a recurved part of the net was constructed to prevent upstream migrants of being washed back by the stream (fig. 3). Since this special type of net for upstream migrants did not catch significantly more animals than the normal drift net placed in opposite sense, in most later experiments a combination of the two nets was used, as illustrated in figs. 4-7. In this combination net, both upstream and downstream migrants at any given place were catched in the same net.

In Stations I to III the nets blocked only a small part of the riverbed. Attempts to block the entire bed by nets (see, for instance, Needham, 1928) always resulted in a failure, since the strong current torn the net, and since floating debris obstructed the meshes.

In Station IV, where the rivulet was much less wide, the entire stream could be fished out.

The interchangeable bags at the end of the nets were lifted every hour, every two hours, or at other regular intervals. It was supposed that, if we fished always on the same spot and lifted the nets at the same time interval, the contents of the bag would consist of a representative sample of the migrating population. Of the contents of every bag a random sample was preserved at once in ethyl alcohol $70^{\circ}$.

The data obtained at the Stations I to IV were completed by dip-net catches at various places all along the stream system.
Table II. Current speed in $\mathrm{cm} / \mathrm{sec}$. in the River Slack at Station I on 11 August 1967.

Explanation see table I. Tidal difference $41 \mathrm{~cm}$.

\begin{tabular}{|c|r|l|}
\hline local time & speed & \multicolumn{1}{|c|}{ remarks } \\
\hline 10.35 & +50 & low tide in open sea, \\
& & temp. $16.2^{\circ} \mathrm{C}$. \\
11.00 & +49 & temp. $16.4^{\circ} \mathrm{C}$. \\
11.30 & +48 & temp. $16.5^{\circ} \mathrm{C}$. \\
12.30 & +49 & temp. $16.7^{\circ} \mathrm{C}$. \\
13.30 & +41 & temp. $17.4^{\circ} \mathrm{C}$. \\
14.30 & +31 & temp. $17.7^{\circ} \mathrm{C}$. \\
14.53 & 0 & highest water level at Station I \\
15.10 & -23 & high tide in open sea, \\
& & temp. $18.2^{\circ} \mathrm{C}$. \\
15.30 & -27 & temp. $18.1^{\circ} \mathrm{C}$. \\
15.55 & -25 & temp. $18.2^{\circ} \mathrm{C}$. \\
17.03 & 0 &.-- \\
17.08 & +10 &.-- \\
\hline
\end{tabular}

Table III. Current speed in $\mathrm{cm} / \mathrm{sec}$. in the River Slack at Station I on 7 September 1967.

Explanation see table I.

\begin{tabular}{|c|c|c|}
\hline local time & speed & remarks \\
\hline $\begin{array}{r}8.45 \\
8.55 \\
9.55 \\
10.55 \\
11.55 \\
12.45 \\
12.55 \\
13.00 \\
13.03 \\
13.10 \\
13.20 \\
13.25 \\
13.40 \\
13.55 \\
14.05 \\
14.20 \\
14.35 \\
14.50 \\
15.05 \\
15.20 \\
15.25 \\
15.30 \\
15.37 \\
15.45 \\
15.50 \\
15.53 \\
15.58 \\
16.03 \\
16.08 \\
16.13 \\
16.23 \\
16.35 \\
17.00\end{array}$ & $\begin{array}{r}+45 \\
+40 \\
+44 \\
+42 \\
+45 \\
+21 \\
0 \\
-8 \\
-15 \\
-21 \\
-25 \\
-29 \\
-28 \\
-24 \\
-25 \\
-33 \\
-33 \\
-24 \\
-25 \\
-13 \\
-11 \\
-.- \\
0 \\
+16 \\
+36 \\
+63 \\
+69 \\
+57 \\
+59 \\
+50 \\
+57 \\
+58 \\
+49\end{array}$ & $\begin{array}{l}\text { high tide in open sea } \\
\text { highest water level at Station I }\end{array}$ \\
\hline
\end{tabular}




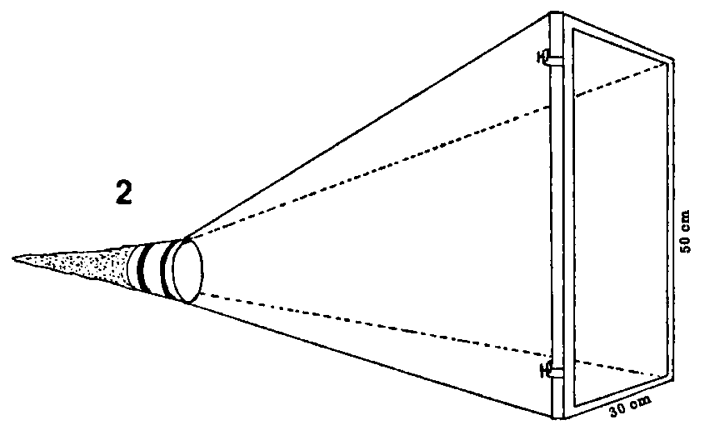

Figs. 2-3. Nets used.

2 , net used for catching downstream migrants; 3 , net used for catching upstream migrants. Later, a combination of these nets was used, see figs. 4-7.
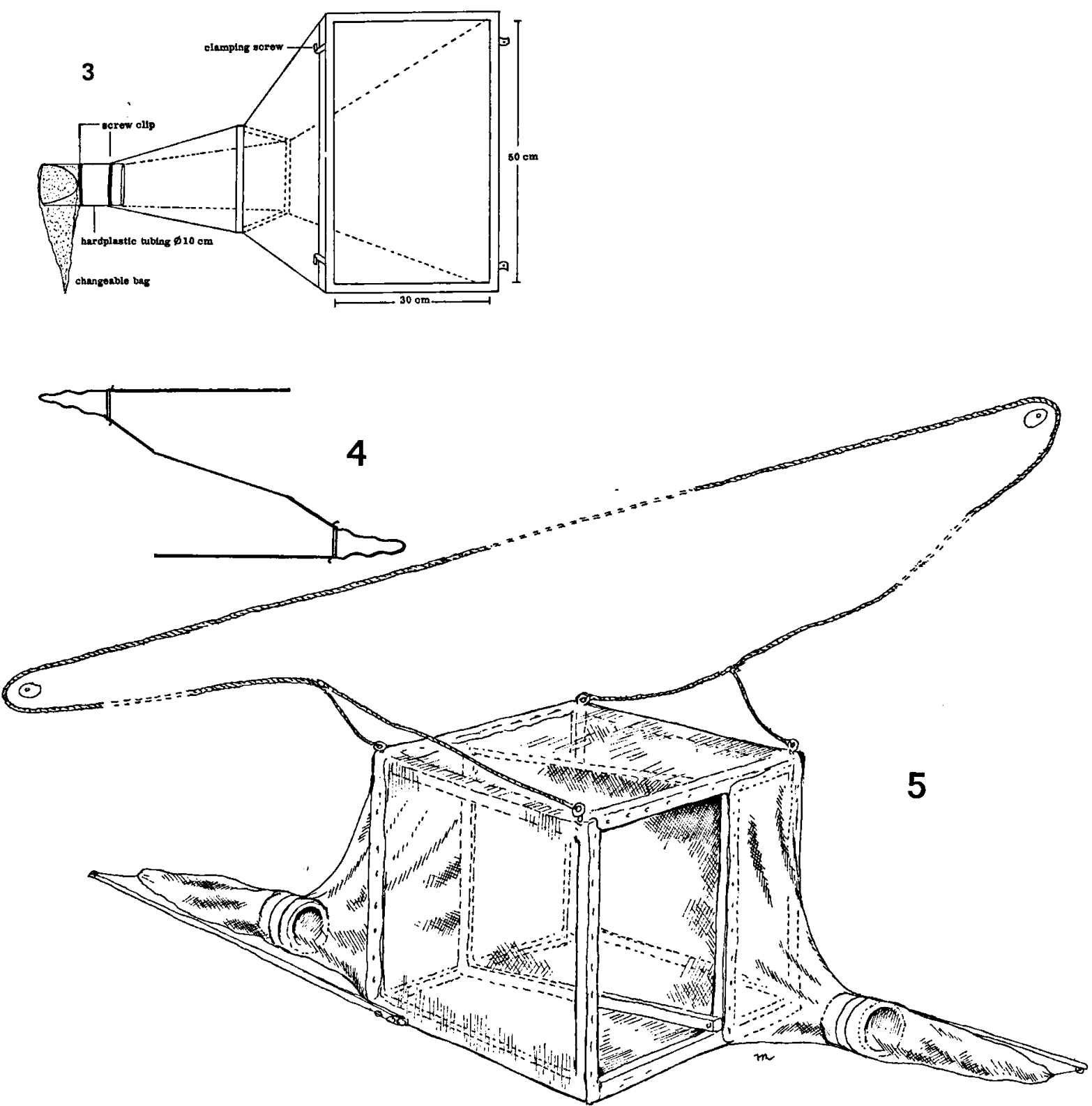

Figs. 4-5. Combination net (to be used for simultaneous catches of upstream and downstream migrants). 4, simplified diagram; 5 , type of net finally used (see also figs. 6 and 7). 

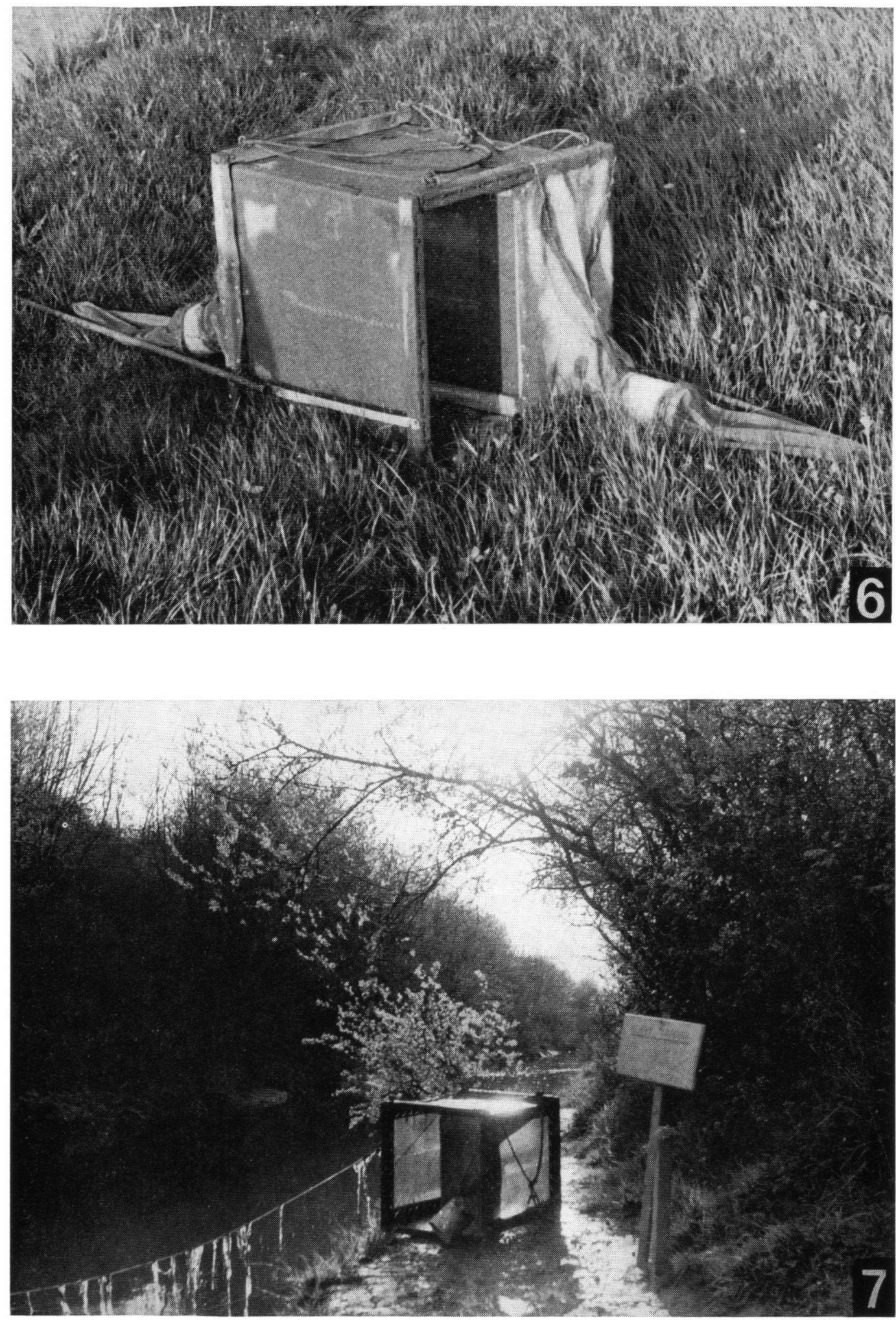

Figs. 6-7. Combination net (see figs. 4-5). 6, exposed on the bank; 7, station I, with the combination net (bags lacking) on the northern bank of the river Slack. 


\section{2) Physico-chemical determinations}

Chlorinity was determined in $\mathrm{mg} / 1$ with the aid of an E.E.L. electric equipment. Both surface and bottom chlorinities were determined.

Stream velocity was estimated at the surface, with the aid of a floating object and a stopwatch.

Temperature readings have been made with the aid of a mercurial thermometer (scale in $0.1^{\circ} \mathrm{C}$.).

\section{3) Further treatment of the material}

The net catches were preserved and later studied in the laboratory. Under a dissecting microscope the animals were divided into three groups: juveniles (that remained unsexed), males, and females. According to a method developed by Kant (see $\$ \mathrm{~V}$ ), animals in which the spines on the posterior margin of the 7 th leg are longer than the accompagnying setae, were classified as juveniles. The adults were sexed, according to the presence or absence of calceoli on the second antenna, and to the characteristics of the medial palmar spine of the second gnathopod (cf. Sexton, 1912; Spooner, 1947; Segerstråle, 1947). Usually 100 animals of each sample were measured and sexed.

\section{4) Measurements}

It proved not to be easy to measure the body length of the animals collected, because of the commashape of the body. Instead, the length of the hardly bent cephalic segment was measured, along the dorsal side, from the distal end of the rostrum to the articulation with the first pedigerous segment.

These measurements could be made rapidly under a compound microscope with the aid of an eye-piece micrometer.

As is shown in fig. 8, there is a linear correlation between the cephalic length and the body length.

The various size classes obtained by measurements were finally plotted and the difference found between catches of various dates were tested statistically with the t-test (according to Wijvekate, 1966).

\section{5) Tagging}

It proved to be possible to place a paint mark on the dorsum of live gammarids, which remained visible until the next moult. This tagging was done with a synthetic luminescent paint, brand Fluorart (manufactured by Winsor \& Newton Ltd., London). This paint is manufactured in 16 colours, five of which were currently used in our experiments, viz., white, yellow, red, green, and blue.

Live gammarids are placed on a sheet of filter paper, where they are left to dry for 10 to 20 seconds. Then, with a thin, obtuse probe, one or more dots of paint in one or more colours are applied to the dorsal surface of the metasome, while care is taken not to touch the appendages. At once after the tagging, the animals are placed back in a container with river water. According to the handiness of the ex-

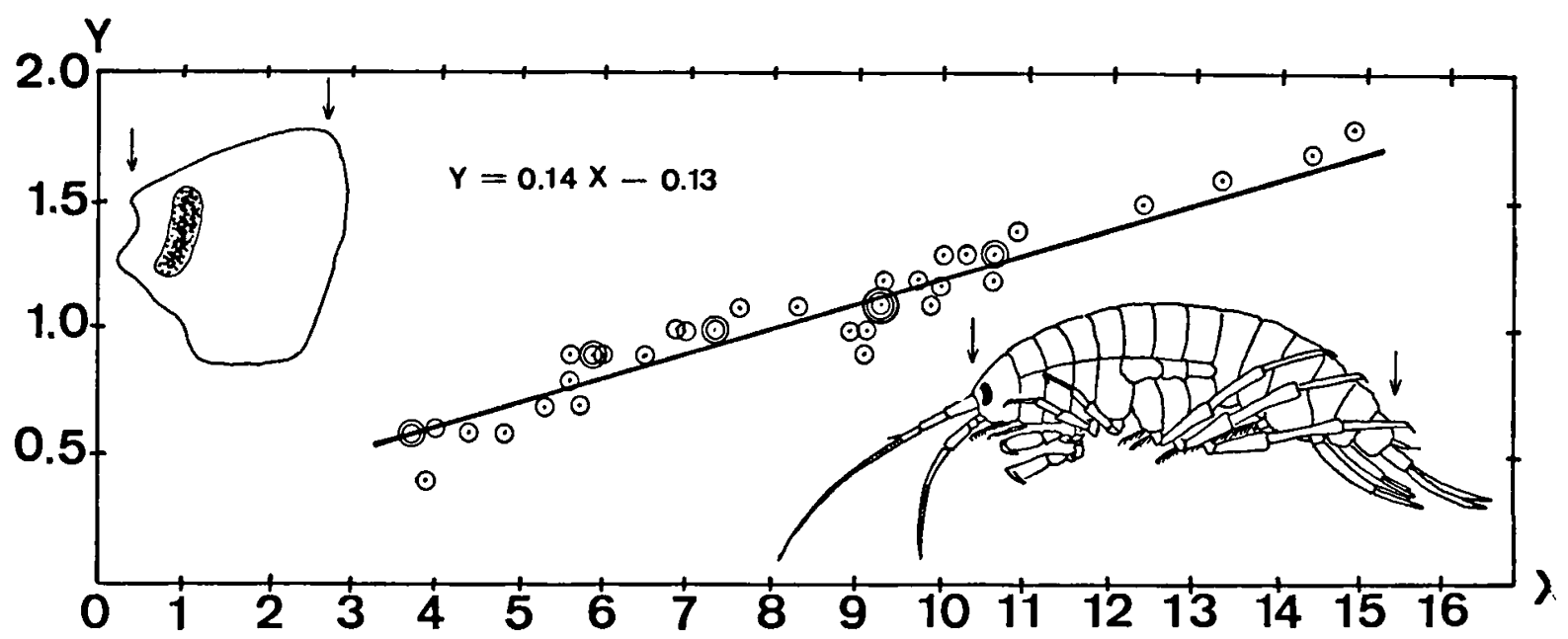

Fig. 8. The relation between body length (plotted on the $x$-axis) and cephalic length (y-axis) in Gammarus zaddachi $(n=40)$. The points found, group clearly along a straight regression line, calculated as $y=0.14 x-0.13$. 
perimentator, the percentage of individuals that suffers noticeably from this treatment varies between 0 and $10 \%$. Finally, the tagged animals that appear in good condition are released at a given place and the percentage of recaptures is noted. So, the distance and direction of the migration, as well as part of the day during which the migration took place, could be studied.

\section{ACKNOWLEDGEMENTS AND}

\section{RESPONSABILITIES}

The research was started and coordinated by the senior author (J.H.S.), assisted in various phases of the fieldwork by B.Sc. students working for their degree. Thus, the growth sequence, and the characters to identify the various growth stages, were studied by Mr. P. Kant. The downstream drift at Station IV by Drs. S. Pinkster. The distance of migration in one night (studied through experimental tagging) was worked out by Dr. J. H. Stock for the downstream migration and by Mr. H. G. Dennert and Mrs. A. L. Dennert for the upstream migration. The last-named two also took care of the year-cycle at Stations I to III, sometimes assisted by the others, but mostly ulone, and of the preparation of the graphs published in this paper.

The authors are greatly indebted to Professor $\mathrm{H}$. Boulangé, of the Faculté Libre des Sciences de Lille, Director of the fieldstation called "Laboratoire Ch. Maurice" at Ambleteuse-sur-Mer (département Pasde-Calais), France, who has put the facilities at our entire disposal, winter and summer, day and night, as a base for the fieldwork.

The fieldwork has been made possible by grants of the University of Amsterdam (to some of the B.Sc. students) and of the Beijerinck-Popping Foundation of the Royal Netherlands' Academy of Sciences, Amsterdam (to the senior author). We want to express our gratitude for this financial support.

\section{RESULTS}

\section{GROWTH OF GAMMARUS ZADDACHI}

\section{1) Range of G.zaddachi and G.salinus}

At the start of our investigations concerning the distribution of the various species of Gammaridae in the river Slack and its estuary, we used Kinne's nearly classical key (1954) to identify the members of the genus Gammarus. Kinne's key has the advantage that both adult and juvenile characters are taken into consideration, and that nearly all key characters are illustrated.
The distribution pattern resulting from this procedure in the Slack is essentially that published later by Stock, Nijssen \& Kant, 1966, fig. 1. However, a very curious inconsistency resulted from these initial investigations: the mouth of the estuary was inhabited, among others, by G.salinus; this species was replaced, towards the head of the estuary, by G.zaddachi; the latter species penetrated also a certain distance upriver into the fresh-water tidal reaches of the Slack; still farther up-river, however, G.salinus showed up again, living at chlorinities as low as $0.04 \%$. Such distribution was contradictory to the pattern found elsewhere along the European coasts, where G.salinus is found only in those parts of the estuaries with the highest salinities (cf. Segerstråle, 1947; Spooner, 1947; Kinne, 1952).

\section{2) Trickery - salinus}

It was thought worth while to investigate the freshwater occurrence of the alleged G.salinus more closely. In the next discussion, these fresh-water gammarids, having the key characters (according to Kinne, 1954) of G.salinus, but living up-river instead of down-river of the area inhabited by G.zaddachi, will be called "trickery-salinus", in order to distinguish them from both the real salinus and zaddachi.

For the distinction of G.salinus and G.zaddachi, we chiefly used the classical method, developed bv Sexton (1912, 1913, 1942), Spooner (1947), Segerstråle (1947), and used as a key character by Kinne (1954), according to which salinus is characterized by the presence of short setae (shorter than the spines) on the posterior margin of segment 4 of leg 7 , whereas in zaddachi the setae on this place, in particular those of the apical and subapical groups of elements, are much longer than the spines. This difference seems trifling, and indeed, salinus and zaddachi were considered a long time two forms of the same species, a "spiny" form from higher salinities, and a "hairy" form from lower salinities (Sexton, 1942). But since Spooner (1947) showed that both forms were separated by a reproductive barrier, Kinne (1954) rightly took the step of considering them (sibling) species.

Trickery-salinus belongs morphologically to the salinus-zaddachi-group, characterized as it is by a setiferous peduncle of its first antenna, and by a distinctive armature of the lower margin of the third segment of the mandible palp. On the posterior margin of the 4th segment of leg 7 of trickery-salinus, the setae are shorter than the spines, which classifies it consequently with G.salinus. 
It is true that Kinne's key is based primarily upon adult males, but in the same publication it is stated that shorter or longer setation is little age dependent, and that the salient setal length-spine length ratio could be used with success in animals even smaller than 4 to $6 \mathrm{~mm}$ body length.

Since our trickery-salinus had body lengths from 4 tot $11 \mathrm{~mm}$, no difficulty was expected in the beginning.

It was attempted first to find in nature ovigerous specimens or couples in the precopula stage of the trickery-salinus. These attempts were all in vain. The problem could have three possible answers: trickerysalinus are juveniles of

a) the species G.salinus

b) the species G.zaddachi

c) another species at the moment unknown to us.

Possibility b) was rejected in earlier stages of our study, as it was in contradiction to Kinne's statement that the morphology of segment 4 in leg 7 was already typically developed in $4 \mathrm{~mm}$ juveniles.

As to possibility c), no described species ${ }^{1}$ ) fitted the material of trickery-salinus.

\section{3) Morphological comparison of trickery-salinus with salinus and zaddachi}

Preserved samples of trickery-salinus (from the river Slack), of salinus (from Germany, The Netherlands, and the river Slack), and of zaddachi (from Germany, The Netherlands, Wales, and the river Slack) were subjected to a scrutinous, morphological examination. The following seven characteristics have been compared: (1) the setation of the lower margin of the pedunculus of the first antenna; (2) the number of segments in the accessory flagellum; (3) the shape of the propodus of the two gnathopods; (4) the armature of leg 7; (5) the shape and armature of the 2nd and 3rd epimeral plates; (6) the dorsal armature of the urosome; and (7) the armature of the telson lobes.

It appeared that these characters in G.salinus and G.zaddachi showed a considerable overlap, but that the statistical means usually were different. On the basis of characters (1), (2), and (5), no decision could be reached whether trickery-salinus showed more resemblance to zaddachi or to salinus. On the basis of the remaining characters - (3), (4), (6) and (7) trickery-salinus showed closer relations to zaddachi

1) With the exception perhaps of Gammarus sarsi Reid, 1943 (= G. ochlos Reid, 1945) which is, however, synonymous with G. zaddachi (see Segerstråle, 1947, and Stock \& Kant, 1966). than to salinus. However, in the light of the great overlap shown by all characters, no clear decision could be reached as to the taxonomic status of trickery-salinus. The only thing that emerged from these morphological comparisons was, that trickery-salinus had not a single absolutely distinctive feature of its own, and that all its characters fell within the range of variation of the zaddachi-salinus-complex.

Certain indications pointed in the direction that trickery-salinus was the juvenile phase of G.zaddachi: a number of morphological details showed this tendency, and the distributional range (overlapping with zaddachi, disjunct from that of salinus) formed a clue as well.

In order to put down all incertitudes, trickerysalinus was brought in culture in the laboratory and its morphological changes were followed.

\section{4) Rearing experiments}

On 4 August 1966, 140 specimens of G.zaddachi were caught in the estuary of the Slack. The chlorinity at the moment of collecting was $11.0 \%$.

On 5 August 1966, 840 specimens of trickerysalinus were caught in a tributary of the river Slack, the Rivière de Bazinghen, off the farms La Parthe and Otove. The chlorinity at the moment of collecting was $0.05 \%$.

All these animals were transported by car over 500 $\mathrm{km}$ to Amsterdam, in insolated cooled jugs. In the laboratory they were placed in fingerbowls, surface $40 \mathrm{~cm}^{2}$, waterdepth $5 \mathrm{~cm}$, chlorinity $0.8 \%$. Each bowl contained 15 gammarids. The temperature in the culture room was buffered to all too sudden changes, but followed otherwise the more periodic changes of the open air. Food was given in accordance with Sexton's (1928) directions.

Although the initial mortality was high, the culture was continued until 3 March 1967. In this period, the chlorinity was raised two times: After 110 days, starting on 23 Nov. 1966, the chlorinity was gradually raised to $3.47 \%$. This value was attained on 2 Dec. Starting on 12 Dec., the chlorinity was gradually raised to $6.8 \%$, a value attained on 30 Dec.

Every week, a number of animals, by preference 15 , from the culture were taken out and preserved in alcohol. So, the morphological changes as the time passed by, could be followed.

\section{5) Changes in morphology during the growth}

In fig. 9 the ratio length longest seta/length longest spine is plotted. In the left column, the spines and setae of segment 4 of leg 7 are incorporated, in the 


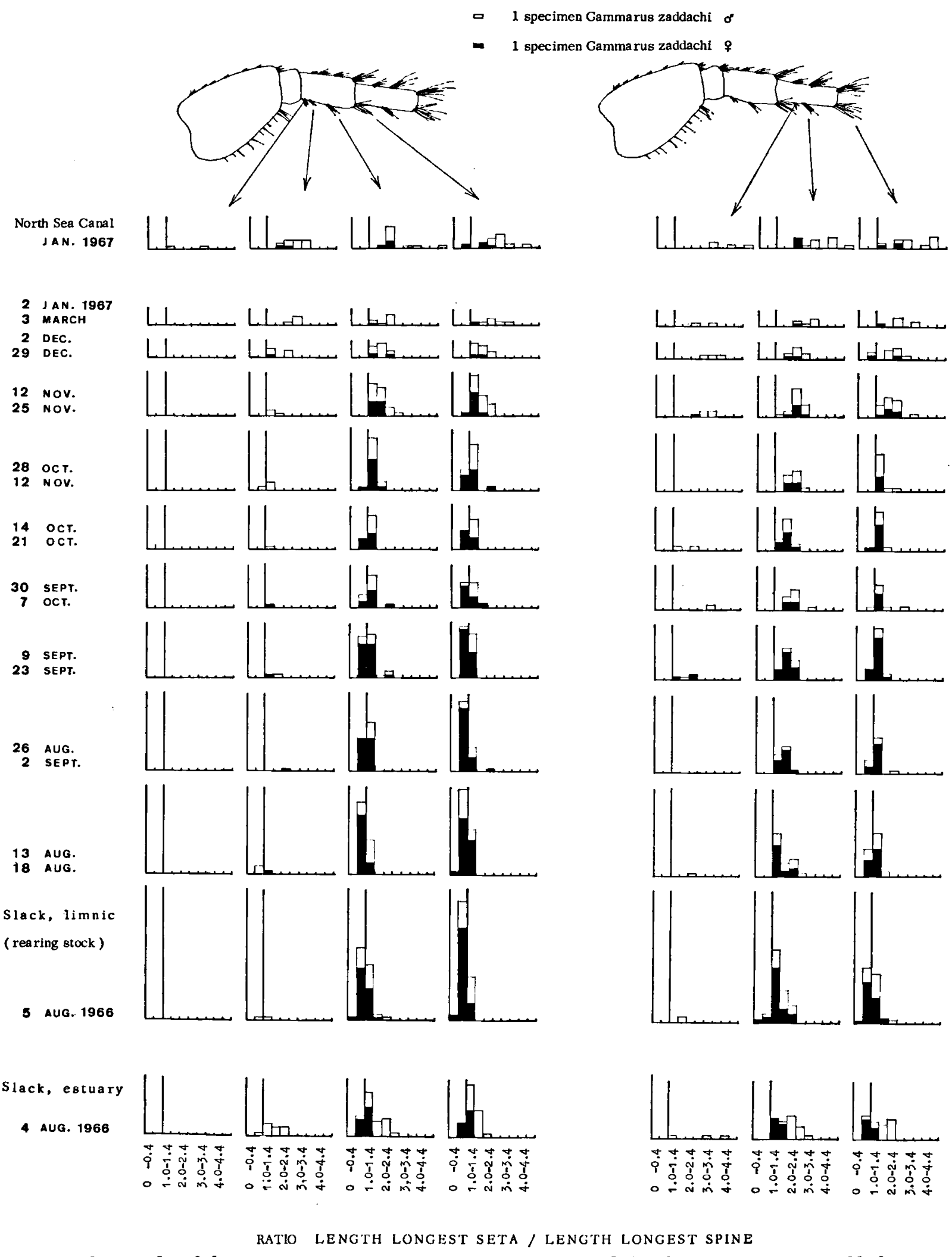

Fig. 9. The ratio length longest seta/length longest spine on segments 4 and 5 of leg 7 in Gammarus zaddachi from different localities and reared in the laboratory. This ratio is currently used to discriminate taxonomically between Gammarus zaddachi and Gammarus salinus. Explanation see text ( $\$$ V.5). 
right column those of segment 5 of leg 7 . Since segment 4 usually has 4 groups (bunches) of elements ${ }^{1}$ ), the left column is subdivided into 4 vertical rows of block diagrams. The 3 vertical rows of block diagrams in the right column correspond with the 3 groups of elements on segment 5. (See illustration of leg 7 at the top of both left and right column). The females are indicated by solid (black) blocks, the males by open (white) blocks in the diagrams.

The figures on the absciss indicate how many times the longest seta is longer than the longest spine (thus 4.0 - 4.4 means that the longest seta is $4.0-4.4$ times longer than the longest spine).

On the ordinate, groups of animals preserved at different dates are indicated. The lowest row (marked "Slack, estuary"), contains the data on the animals collected in nature in the estuary on 4 Aug. 1966, identified as true G.zaddachi; the next lowest horizontal row (marked "Slack, limnic") contains the data on the animals collected in nature up-river on 5 Aug. 1966, called provisionally trickery-salinus.

In the top row (marked "North Sea Canal"), a number of animals from this Canal (situated in The Netherlands, chlorinity in nature $1.4 \%$ ) has been included for comparison.

The remaining horizontal rows represent animals from the rearing stock, preserved at regular intervals of time.

A vertical line (division line) in each block diagram indicates the key value in the seta-spine ratio, the key value used in the literature to discriminate $G$. zaddachi from G.salinus. This key value is 1.0 , because if the spines are longer than the setae, the ratio is $<1.0$, and the animal in question classifies with G.salinus. If the setae are longer than the spines, giving a ratio $>1.0$, the animal classifies with $G$. zaddachi.

The following conclusions can be drawn from fig. 9: (1) Material collected in the areas with a higher salinity (lowest row, marked "Slack Estuary, 4 Aug. 1966") consists for the greater part of animals in which the setae are longer than the spines (this means that the greater part of animals are plotted to the right of the line separating typical zaddachi from typical salinus). This is especially true for the males; of the females a certain percentage turns out to fall to the left of the division line.

(2) Material collected in areas with a low salinity (row marked "Slack, limnic, 5 Aug. 1966") chiefly is grouped closely around the division line, which means that setae and spines are about equal in length.

1) Elements = spines and setae together.
(3) Members of the population mentioned under (2), reared in the laboratory (rows marked 13 Aug. 1966 to 3 March 1967) show a gradual shift in the seta/ spine ratio. On 5 Aug. setae and spines are still subequal, but later in the year in the majority of the specimens (in particular the males), the setae outgrow the spines. In October the males have attained a typical zaddachi habit, which was maintained during the rest of the experiment. After October the length growth of the setae continues, the highest ratio being reached in March (at the end of the experiment).

(4) The same increase in length of the setae during the period the animals were in culture is observed for segment 5 of leg 7 (right column in fig. 9), although distinct zaddachi-like morphology is reached in this segment earlier in the year than in segment 4 .

\section{6) Conclusion of the rearing experiments}

The setae on the posterior margin of segment 4 in leg 7 (which are currently used to discriminate between G.zaddachi and G.salinus) are still short in summer, but increase in length during autumn and winter. Since summer animals are sexually inactive (see $\$ \mathrm{~V}-2$ ) and since they are of smaller size than winter specimens (see $\$$ XIV-2, XIV-3), it is justified to conclude that juveniles up to a certain size still have short setae (thus resemble morphologically the adults of G.salinus, and hence called "trickery-salinus" in the previous treatment), but that their morphology develops later in the year to that of real G.zaddachi.

\section{7) Correlation between absolute size and morphology}

Kinne, 1952, states that females of G.zaddachi attain sexual maturity at a body length of about $7 \mathrm{~mm}$. Since the body length and the cephalic length are in linear proportion to one another (see $\$$ III-4), it can be deduced from fig. 8 that a body length of $7 \mathrm{~mm}$ corresponds with a cephalic length of about $0.9 \mathrm{~mm}$. The diagram (fig. 10) shows the seta/spine ratio in leg 7 for two size classes of Gammarus zaddachi, viz. of $0.60-0.79 \mathrm{~mm}$ and of $0.80-0.99 \mathrm{~mm}$ (cephalic length). In the left vertical row, the ratio longest seta/longest spine is given for each of the three groups of elements on segment 4 of leg 7 , in the right vertical row for segment 5 of leg 7. In the smaller size class, the setae on segment 4 are as a rule shorter than the spines, in the larger size class, about equal numbers of animals have the spines longer than the setae and the setae longer than the spines. 
H. G. DENNERT ET AL.
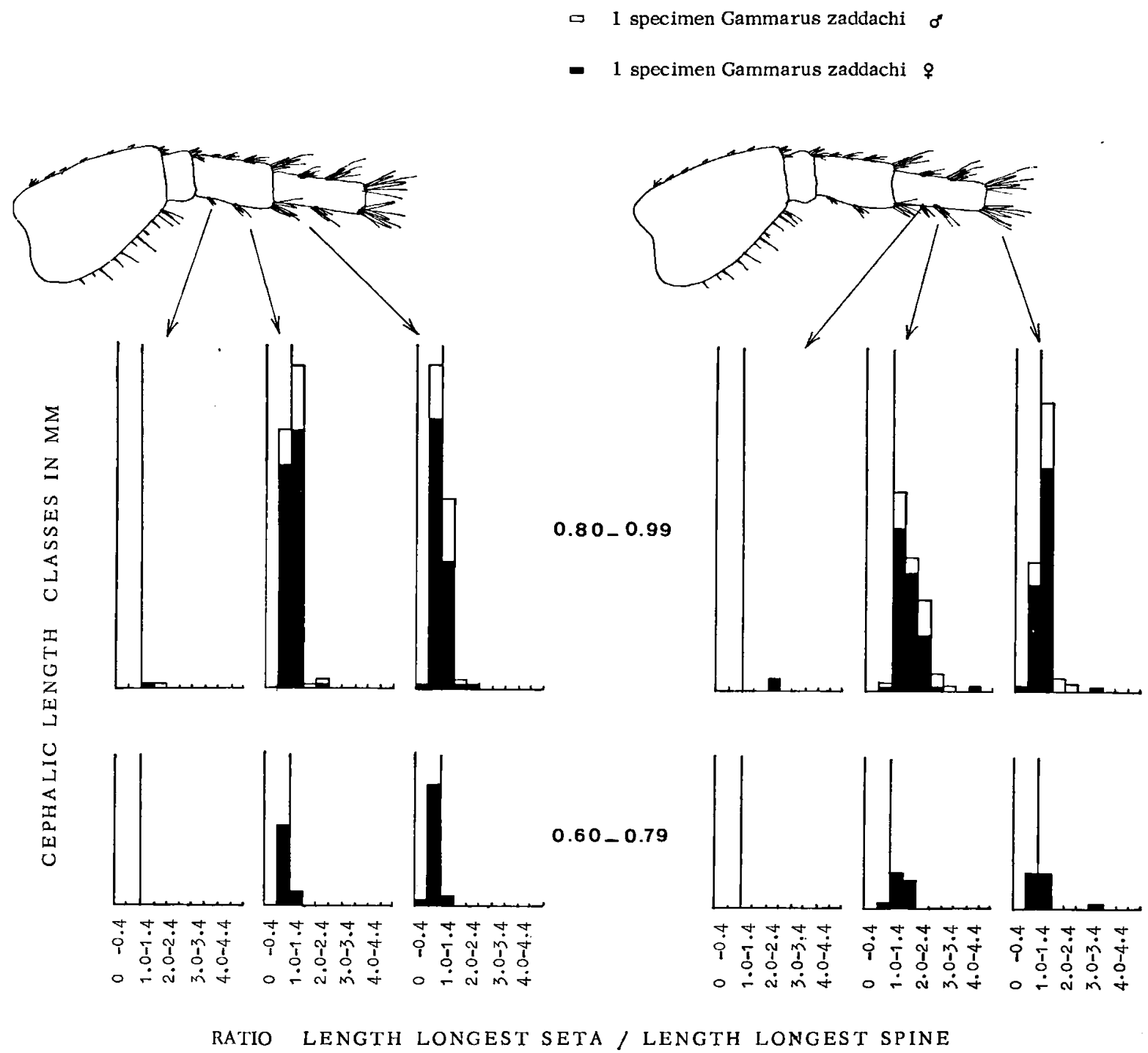

Fig. 10. The ratio length longest seta/length longest spine on segments 4 (left column) and 5 (right column) of leg 7 in two size classes of Gammarus zaddachi. Lower row: cephalic length $0.60-0.79 \mathrm{~mm}$. Upper row: cephalic length $0.80-$ $0.99 \mathrm{~mm}$. Explanation see $\$$ V. 7 .

The key value of 1 (meaning setae and spines of same length) is reached, as is apparent from fig. 10, in the size class of $0.80-0.99 \mathrm{~mm}$ cephalic length. Specimens with a key value lower than 1 ( $=$ setae shorter than the spines) have been considered by us as juveniles. This assumption corresponds very well indeed with Kinne's observation that animals smaller than $7 \mathrm{~mm}$ total length $(=0.9 \mathrm{~mm}$ cephalic length) are immature.

Of course, the lengths (total length or cephalic length) are rather imperfect expedients, but convenient in handling large numbers of animals. Ac- tually, sexual maturity is reached by females having completed the development of the setae on the oostegites (cf. Sexton, 1924), but this character lends itself less for mass treatment.

\section{8) The distinction of the two sibling species, G.zaddachi and G.salinus}

We have seen in a preceding paragraph (see $\$ \mathrm{~V}-6$ ) that juveniles of G.zaddachi resemble in the setation of their seventh leg (the character usually employed for the distinction of zaddachi and salinus) the adult 
stage of G.salinus. The question then arises, whether there could be found an easily observable morphological character that is workable also for the younger stages.

a) It was shown (figs. 9, 10) that especially segment 4 of leg 7 was less suitable as a salient character. From these figures, it emerges that the ratio longest seta/longest spine is more useful in segment 5 of leg 7. We tested 430 specimens of G.zaddachi, with cephalic lengths ranging from 0.4 to $2.0 \mathrm{~mm}$, for this character. Only 24 out of these $(=5.5 \%)$ showed setae shorter than the spines. These 24 exceptions were not necessarily the smallest animals, their cephalic lengths ranged from 0.4 to $1.3 \mathrm{~mm}$. No exceptions for this character were found among 52 specimens of G.salinus, cephalic lengths $0.6-1.6 \mathrm{~mm}$. Both the zaddachi and the salinus material was collected at a number of different localities in The Netherlands, Denmark, Germany, and France.

b) Spooner, 1947, mentions that in G.zaddachi the posterior margin of segment 2 of leg 7 is armed with setae - though variable in length - of which at least $50 \%$ is clearly longer than the intervals between successive setae. In salinus, these setae are - according to Spooner - shorter than the intervals separating adjacent setae.

We have tested this feature on its possible taxonomic value. The left vertical row in fig. 11 shows, in almost complete analogy with Spooner, the quotient, $A=\frac{S_{m}}{D_{m}}$. In this quotient, $S_{m}$ stands for the mean of the 3 longest setae, $D_{m}$ for the mean of 3 intersetal intervals chosen at random.

Per size class of $0.1 \mathrm{~mm}$ cephalic length, the block diagrams for G.zaddachi $\delta$ and $\$$, and for G.salinus $\delta$ and $\phi$, are usually separate but adjacent. At the top of the left row, the totals for all size classes and both sexes are plotted; here also we observe different statistical means for zaddachi and salinus, and only a narrow zone of overlap. Complete separation of the curves for zaddachi and salinus only is found in the cephalic length classes larger than $1.30 \mathrm{~mm}$.

Although this character gives satisfactory results in several cases, and although it is easily observable, by estimation and without taking precise measurements, it suffers from a draw-back. The number of setae increases with increasing age. This increase in number is achieved by subdivision of the existing intervals between the setae, resulting in smaller and smaller intervals.

c) To cope with this difficulty, the ratio, $B=\frac{W}{S_{m}}$ has been calculated, in which $\mathrm{W}$ is the maximal width of the second segment of leg 7 , and $S_{m}$ is the mean length of the three longest setae. This ratio is plotted in fig. 11, right vertical column. The advantage of this method is that the intersetal interval (which is age-dependent) is no longer used. The disadvantage is that the ratio $\mathrm{W} / \mathrm{S}_{\mathrm{m}}$ cannot be estimated but must be based on measurements with an eye-piece micrometer.

Also in the $\mathrm{W} / \mathrm{S}_{\mathrm{m}}$ ratio, some overlap between zaddachi and salinus is found, but the means for each species are more widely separated. In mixed populations of both species, individuals with a $\mathrm{W} / \mathrm{S}_{\mathrm{m}}$ ratio $>10$ belong to G.salinus, those having this ratio $<6.5$ belong to G.zaddachi.

Concludingly, we may say that it is not always easy to distinguish between G.salinus and G.zaddachi. Although the adults (body length $>7 \mathrm{~mm}$ ) are wellcharacterized (by the armature of segment 4 , but particularly of segment 5 , of leg 7 , younger stages of G.zaddachi are more difficult to separate from G.salinus. The length of the setules on the posterior margin of segment 2 of leg 7 (in relation to the intersetal interval or in relation to the width of the segment) forms in most cases a useful additional clue.

\section{DAY - NIGHT PERIODICITY}

\section{1) Introduction}

Several authors (Harker, 1964; Müller, 1963a, 1963b; Waters, 1962a, 1965) have emphasized a day-night rhythm in several limnic invertebrates, including representatives of the Gammaridae. In our study, it was apparent from the beginning that only during the night large numbers of gammarids were taken and never during daytime. Of the 15 species of Gammaridae known to occur in the river Slack and its estuary, only one, Gammarus zaddachi, is found in large numbers in the stream nets. Echinogammarus berilloni (Catta) is regularly found in the downstream nets, but never in great numbers (at most $3 \%$ of the total catch) and never in the upstream nets. It is almost certain then, that feeding animals are involved here. Presumeably these were accidentally carried along by the stream and got into the net.

\section{2) Results}

Like Müller, 1966b, and Jansson \& Källander, 1968, showed for other species, the greatest activity for G.zaddachi also is at night. Figs. 12-14 give the 24hours cycles, as shown in the net catches for downstream migrants, for 3 different dates and stations. 
H. G. DENNERT ET AL.
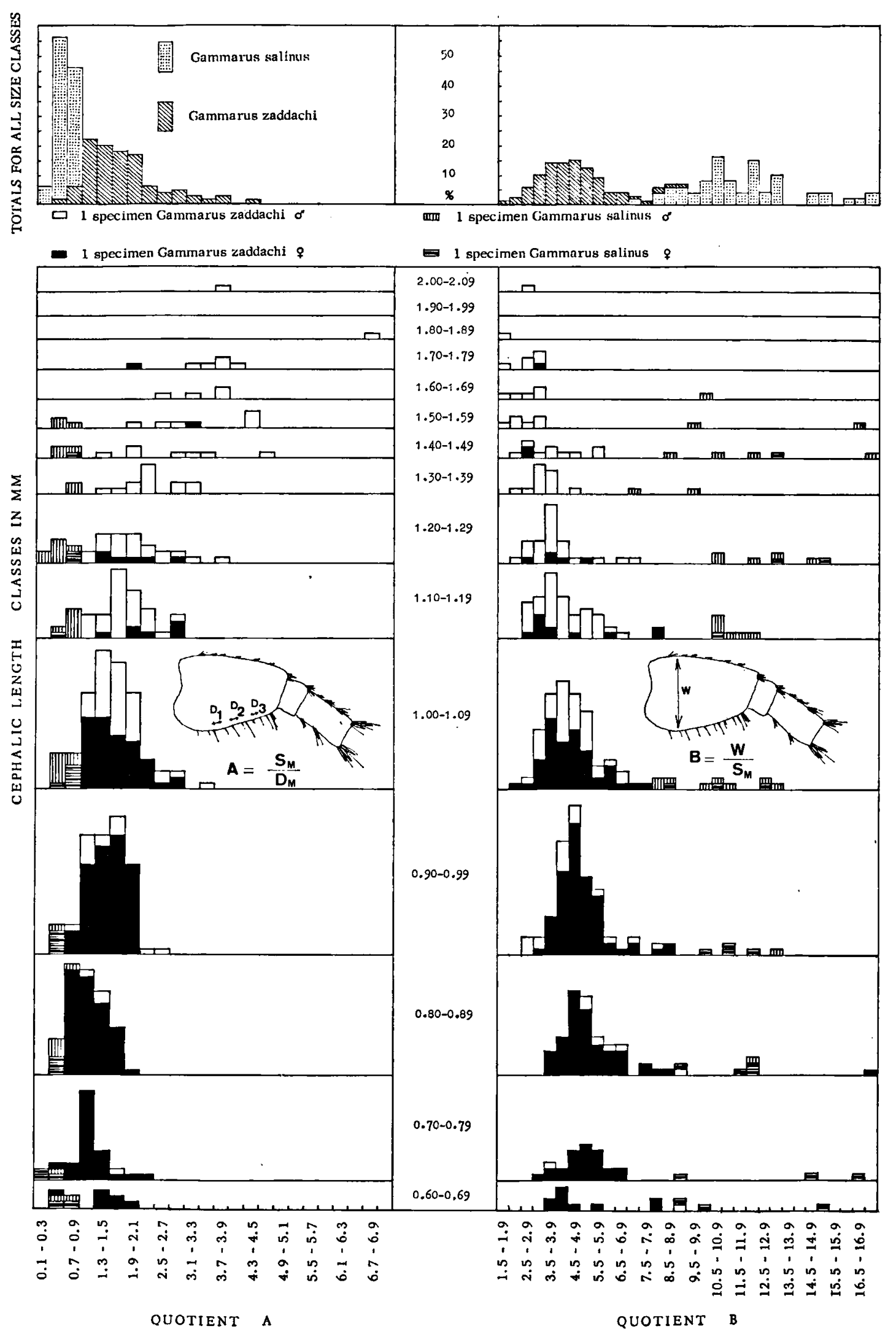
The observations at other stations and dates correspond closely with the data presented in the figure. The following regularities are clear at once:

(1) Downstream migration always takes place in the dark; during daytime, migration activity is virtually absent.

(2) One to two hours after sunset, the migration starts all the sudden and reaches its maximum two to three hours after sunset.

(3) During the rest of the night, the migration continues, but the number of animals participating in it gradually drops. At sunrise, the activity stops entirely.

\section{3) Discussion}

In context with these observations, one would expect that there would exist a relation between the nocturnal activity of the animals, as expressed in the number of individuals caught per unit of time, and the light intensity. Müller (1966a) and Jansson \& Källander (1968) have proved, in laboratory experiments, that a dropping light intensity increases the activity in G.pulex (Linnaeus) and G.oceanicus Segerstråle. Also Waters (1962a) drew the same conclusions on nocturnal activity from his field observations on G. limnaeus Smith.

While we agree with these authors in that G.zaddachi shows a marked day-night rhythm, with a nocturnal activity period, we could not clearly prove a correlation between the activity on dark nights and on clear nights. As is shown in table IV and fig. 16, there is no logic correlation between the brightness of the night and the number of gammarids in the catches. The activity peak just after sunset is shown also by other organisms, such as Ephemeroptera and Chironomidae (see McLay, 1968, who postulates a mechanism for this activity pattern).

There is a clear correlation, however, with the migratory activity and the spring-tides, irrespective of the fact whether a new moon or a full moon springtide is involved.

Anticipating on the facts exposed in the sequel, it might be remarked that upstream migration also takes place at night, however, not during every night, but only during a narrow period around the spring-tides.

\section{INFLUENCE OF THE SPRING-TIDE ON THE MIGRATORY ACTIVITY}

\section{1) Stream}

As shown in fig. 16, daily observations have proved a marked difference between the catches during nights with spring-tides and other nights. As described above, in \$II ("Study area and environment"), the Stations I to IV are separated from the open estuary by an imperfectly operating automatic sluice. The tidal difference, which is 8 to 9 meters at springcide in the open sea off the estuary, may cause a nse of the river level of 0.30 to $1.0 \mathrm{~m}$ at Station I. This rise is usually coupled with a reversal of the direction of the current (fig. 15). Under "normal" conditions (i.e., no excessive rainfall, no H.W.S.) the river flow at Station I amounts to 40 to $50 \mathrm{~cm} / \mathrm{sec}$., in seaward direction, of course. Fig. 15 shows, that the stream velocity drops some two hours before H.W.S. One hour before H.W.S., the water stands still, and from then on, till approximately an hour after H.W.S., the direction of the current reverses $180^{\circ}$, whereas finally - after a short second standstill period - the river flow re-assumes its normal direction and speed. Tables I to III show the reversal at the stream at various dates in Station I.

In Stations II to IV, the stream reverses as well, but the phenomenon is less marked, due to the greater distance from the sea of these stations.

Table IV and fig. 16 demonstrate that upstream migration of any importance is limited to nights with spring-tides during which the current reverses.

Figs. 17 and 18 demonstrate that upstream migration is limited moreover to the very hours during the night that the current is reversed. During the short period of current reversal ( 2 to 3 hours), the downstream migration practically comes to a stop, whereas the numbers of animals participating in the upstream migration are much larger than those migrating downstream. In a later paragraph $(\$ \mathrm{IX})$ this phenomenon will be worked out.

Fig. 11. Graphic representation of the length of the setules at the posterior margin of segment 2 of leg 7 in Gammarus zaddachi. In the left column this length is expressed as $A=\frac{S m}{\mathrm{Dm}}$ (see $\$ V .8$. b), in the right column as $\mathrm{B}=\frac{\mathrm{W}}{\mathrm{Sm}}$ (see $\$ \mathrm{~V}, 8 . \mathrm{c}$ ). Each horizontal row represents a size class (expressed in cephalic length). At the top, the values for each column have been added up. 
Table IV. Numbers of animals caught per net at night (Station I, August 1968) and environmental factors during the catch.

\begin{tabular}{|c|c|c|c|c|c|c|c|c|c|}
\hline \multirow{2}{*}{ night of } & \multicolumn{2}{|c|}{ numbers caught } & \multirow[b]{2}{*}{ sunset } & \multirow{2}{*}{ high tide } & \multirow{2}{*}{ low tide } & \multirow[b]{2}{*}{ moonrise } & \multirow[b]{2}{*}{ moonset } & \multirow{2}{*}{\multicolumn{2}{|c|}{ remarks }} \\
\hline & $\begin{array}{c}\text { up- } \\
\text { stream }\end{array}$ & $\begin{array}{l}\text { down- } \\
\text { stream }\end{array}$ & & & & & & & \\
\hline $\left.2 / 3^{2}\right)$ & 3 & 160 & $20.26 \mathrm{~h}$ & $6.02 \mathrm{~h}$ & $0.39 \mathrm{~h}$ & $13.04 \mathrm{~h}$ & $23.38 \mathrm{~h}$ & d.n./r. & n.c.r. \\
\hline $\left.4 / 5^{2}\right)$ & 0 & 200 & $20.23 \mathrm{~h}$ & $19.52 \mathrm{~h}$ & $3.14 \mathrm{~h}$ & $17.52 \mathrm{~h}$ & $0.02 \mathrm{~h}$ & d.n./r. & n.c.r. \\
\hline $6 / 7$ & 9 & 210 & $20.20 \mathrm{~h}$ & $22.32 \mathrm{~h}$ & $4.38 \mathrm{~h}$ & $19.50 \mathrm{~h}$ & $3.28 \mathrm{~h}$ & d.n./r. & n.c.r. \\
\hline $8 / 9$ & 2 & 230 & $20.17 \mathrm{~h}$ & $0.30 \mathrm{~h}$ & 19.13h & $20.50 \mathrm{~h}$ & $6.19 \mathrm{~h}$ & $\begin{array}{l}\text { l.n. } \\
\text { much plant }\end{array}$ & $\begin{array}{l}\text { n.c.r. } \\
\text { debris }\end{array}$ \\
\hline $\left.10 / 11^{1}\right)$ & 1600 & 1130 & $20.14 \mathrm{~h}$ & $1.50 \mathrm{~h}$ & $20.42 \mathrm{~h}$ & $21.25 \mathrm{~h}$ & $8.56 \mathrm{~h}$ & l.n. & c.r. \\
\hline $\left.12 / 13^{1}\right)$ & -.. & 950 & $20.08 \mathrm{~h}$ & $2.57 \mathrm{~h}$ & $21.52 \mathrm{~h}$ & $21.52 \mathrm{~h}$ & $11.20 \mathrm{~h}$ & v.l.n. & \\
\hline $13 / 14$ & 0 & 360 & $20.06 \mathrm{~h}$ & $3.29 \mathrm{~h}$ & $22.55 \mathrm{~h}$ & $22.06 \mathrm{~h}$ & $12.31 \mathrm{~h}$ & l.n. & n.c.r. \\
\hline $15 / 16$ & 0 & 290 & $20.05 \mathrm{~h}$ & $4.43 \mathrm{~h}$ & $23.29 \mathrm{~h}$ & $22.40 \mathrm{~h}$ & $14.52 \mathrm{~h}$ & d.n. & n.c.r. \\
\hline $\left.17 / 18^{2}\right)$ & 3 & 530 & $20.01 \mathrm{~h}$ & $6.04 \mathrm{~h}$ & $1.16 \mathrm{~h}$ & $23.37 \mathrm{~h}$ & $17.04 \mathrm{~h}$ & v.l.n. & n.c.r. \\
\hline $\left.19 / 20^{2}\right)$ & 3 & 100 & $19.57 \mathrm{~h}$ & $20.48 \mathrm{~h}$ & $4.10 \mathrm{~h}$ & $1.14 \mathrm{~h}$ & $18.41 \mathrm{~h}$ & l.n. & n.c.r. \\
\hline $21 / 22$ & 2 & 95 & $19.52 \mathrm{~h}$ & $22.55 \mathrm{~h}$ & $6.07 \mathrm{~h}$ & $3.34 \mathrm{~h}$ & $\ldots$ & d.n. & n.c.r. \\
\hline $23 / 24$ & 7 & 135 & $19.50 \mathrm{~h}$ & $0.21 \mathrm{~h}$ & $19.07 \mathrm{~h}$ & $6.09 \mathrm{~h}$ &.-- & l.n. & n.c.r. \\
\hline $\left.25 / 26^{1}\right)$ & 3500 & 300 & $19.46 \mathrm{~h}$ & $1.28 \mathrm{~h}$ & $20.19 \mathrm{~h}$ &.-- & $20.31 \mathrm{~h}$ & d.n. & c.r. \\
\hline $\left.26 / 27^{1}\right)$ & 4000 & 400 & $19.44 \mathrm{~h}$ & $2.00 \mathrm{~h}$ & $20.54 \mathrm{~h}$ &.-- & $20.46 \mathrm{~h}$ & l.n. & c.r. \\
\hline
\end{tabular}

The hours of high and low tide are based on the open sea data, as announced in the governmental tide tables.

Numbers of animals caught (if greater than 100) have been rounded off to nearest multiple of 5 .

Abbreviations used: d.n. = dark night; l.n. = light night; v.l.n. = very light night; r. = rain; n.c.r. = no current reversal; c.r. $=$ current reversal;.$--=$ no data available; $\left.{ }^{1}\right)=$ highest water level; $\left.{ }^{2}\right)=$ lowest water level.

Figs. 17 and 18 also show that upstream migration is not limited to Station I but that it occurs at the other Stations as well.

\section{2) Salinity}

As shown in the previous paragraph, estuarine waters penetrate in the lower reaches of the river during spring-tides. This fact is of the greatest importance since it results in a sudden change of the environment.

At our Station I, the salinity shows a strong and sudden rise at H.W.S. (cf. tables V-VII). At Station II, salinity changes occur, but are barely perceivable, Stations III and IV have current reversal and level changes correlated with the H.W.S., but do not show salinity changes (they remain fresh). The decreasing influence of the H.W.S. on the salinity from West (= the sea) to East (= the river) is shown in table VIII.

\section{3) Conclusions}

(1) Upstream migrations are correlated at all Stations with the H.W.S. Since the H.W.S. causes at all Stations a current reversal, but only at two Stations (I and II) a rise in salinity, it is safe to assume that it is the reversal of the current direction in the first place that is responsible for the upstream migratory movements. It is to be clearly understood, that the "upstream migration" is meant in a geographic sense, and not in the sense that the animals moving in upstream direction also move against the direction of the normal river flow. On the contrary, they use the short periods of stream reversal for their migratory activities.

(2) Downstream migration is present every night, provided the river flow is in seaward direction, irrespective of moon phase and/or tides.

The phenomenon that G.zaddachi makes use of the direction of the water currents, both for its up-river and for its down-river migrations, is not unique at all in the animal kingdom. Several cases in which the currents are used for horizontal migrations have recently been summarized by Verwey (1966).

\section{THE ANNUAL MIGRATORY ACTIVITY CYCLE}

Fig. 19 shows the number of specimens caught in the upstream (hatched) and downstream (black) nets at Station I in the period of 13 July 1967 to 29 April 1968. 
Not included in fig. 19 is the period of 12 May to 13 July 1967, although sampling was done in this period. The reason for leaving out the data on this period is, that sampling was performed not on the very spot of Station I but at two other places, some 300 and $800 \mathrm{~m}$ upstream of Station I. These two sampling places were abandoned later, since they were situated in parts of the river attracting too many curious spectators, provoking disturbance of the experiments. At any rate, the picture of the months of May through July is thus, that a moderate downstream migration occurred during these months (up to 2000 individuals per net and per night in May, and up to 350 in June and early July); no upstream migration of any importance occurred during this period (maximum number of upstream migrants observed 40 per net and per night).

From fig. 19 it is clear that downstream migration, though in fluctuating numbers, occurs throughout the year. Upstream migrating on the contrary is concentrated in the period of September through November, that is during the equinoxal autumn springtides. The April equinoxal tides do show a slight rise in the upstream migratory activity, but the numbers involved are so low as compared with the autumn migration, that they can be neglected.

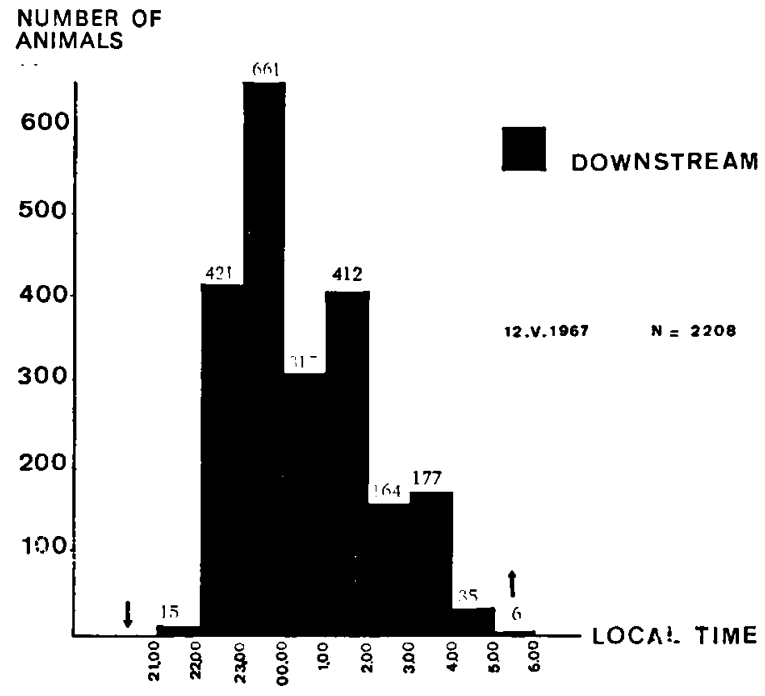

Fig. 12. Numbers of downstream drifters in one night at Station IV. The arrows indicate the time of sunset (arrow pointing down) and sunrise (arrow pointing up).

As it was shown in the previous paragraph, that migratory activity was chiefly concentrated in nights with H.W.S., all sampling was done around the

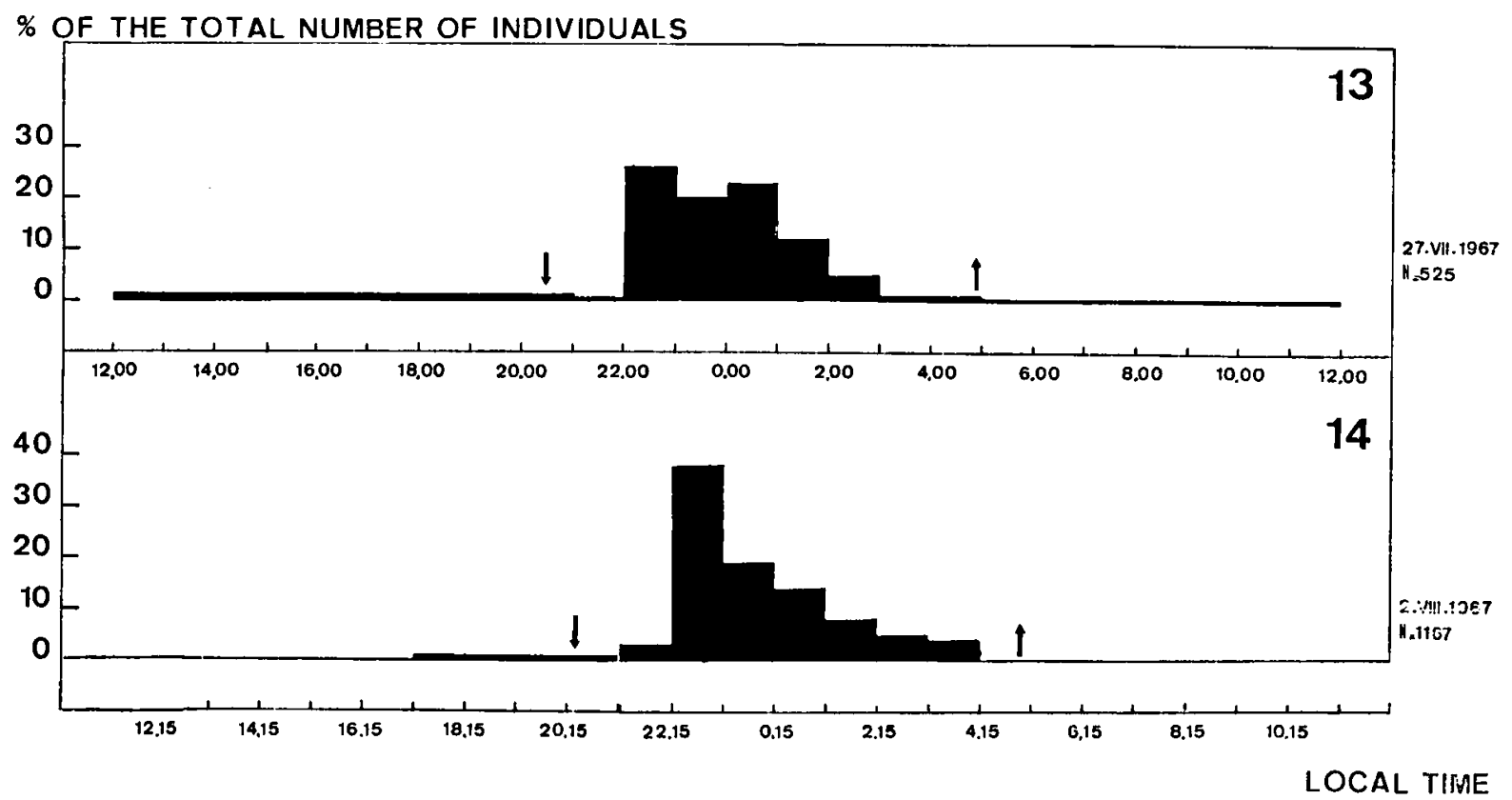

Figs. 13-14. Percentages of the total 24-hours catch per hour of downstream drifters at Station I. Meaning of the arrows as in fig. 12 . 13, on 27 July 1967; 14, on 2 Aug. 1967. 


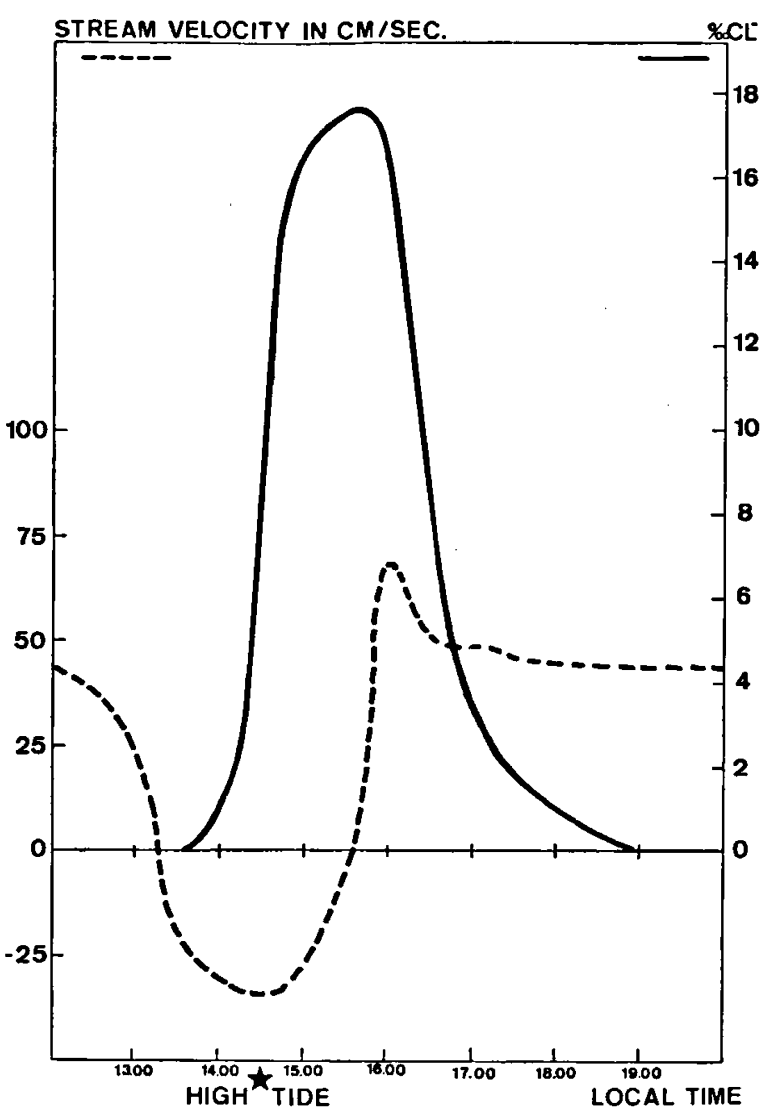

Fig. 15. Stream velocity (broken line) and chlorinity (solid line) during H.W.S. at Station I (7 Sep. 1967).

springtides, with the exception of the data of August 1967 that were collected at narrower intervals.

\section{NUMBER OF MIGRANTS PER NIGHT}

\section{1) Downstream migrants}

The small brook, the Ruisseau de Warem (Station IV in fig. 1), could be totally blocked with our nets without causing serious obstruction in the flow of the brook.

Under these circumstances it is easy to get a good notion of the total number of animals participating in the downstream migration per night. The following data (from Station IV) are available:

2208 individuals - night 12-13 May 1967

1112 individuals - night 17-18 June 1967

2761 individuals - night 23-24 June 1967

At Stations I, II, and III, the river was wider and consequently could not be blocked completely (see \$III.1). Larger nets, such as proposed by Needham
Table V. Chlorinity measurements at Station I on 5/6 September 1967.

\begin{tabular}{|c|c|c|}
\hline local time & chlorinity in \%oo & remarks \\
\hline 19.45 & 0.046 & \\
20.45 & 0.050 & \\
21.45 & 0.048 & \\
22.45 & 0.058 & \\
23.45 & 0.083 & \\
0.45 & 11.2 & high tide in open sea \\
1.45 & 16.9 & at $1.07 \mathrm{~h}$. \\
10.45 & 0.049 & \\
\hline
\end{tabular}

Table VI. Chlorinity measurements at Station I on 7/8 September 1967.

\begin{tabular}{|c|c|c|}
\hline local time & chlorinity in $\%$ remarks \\
\hline 20.45 & 0.049 & \\
21.45 & 0.050 & \\
22.45 & 0.046 & \\
23.45 & 0.076 & \\
0.45 & 0.044 & \\
1.45 & 0.058 & high tide in open sea \\
2.45 & 14.8 & at $2.21 \mathrm{~h}$. \\
3.45 & 17.8 & \\
4.45 & 5.80 & \\
5.45 & 1.20 & \\
\hline
\end{tabular}

Table VII. Chlorinity measurements at Station I on 19/20 September 1967.

\begin{tabular}{|c|c|c|}
\hline local time & chlorinity in $\%$ & remarks \\
\hline 22.00 & 0.057 & \\
0.30 & 7.80 & high tide in open sea \\
1.30 & 16.1 & at $1.00 \mathrm{~h}$. \\
2.30 & 13.1 & \\
3.30 & 0.089 & \\
4.30 & 0.071 & \\
5.30 & 0.049 & \\
\hline
\end{tabular}

(1928) resulted always in a failure, since they were obstructed too soon by floating debris, plants, etc.

Since the nets used at Stations I to III were only $30 \mathrm{~cm}$ wide, and since the river at these stations was approximately 20 times as wide (viz., $6 \mathrm{~m}$ wide), we can - assuming that migration takes place over the entire front at the same rate, and assuming that it takes place entirely in the $50 \mathrm{~cm}$ of water nearest to the bottom ( $50 \mathrm{~cm}$ being the height of our net) estimate that the total migration rate approximately amounts to 20 times the catch per net. Of course, this is a very rough calculation, since the waterlevel changes from 40 to $160 \mathrm{~cm}$. Waters (1965) found no noteworthy difference in vertical abundance of 


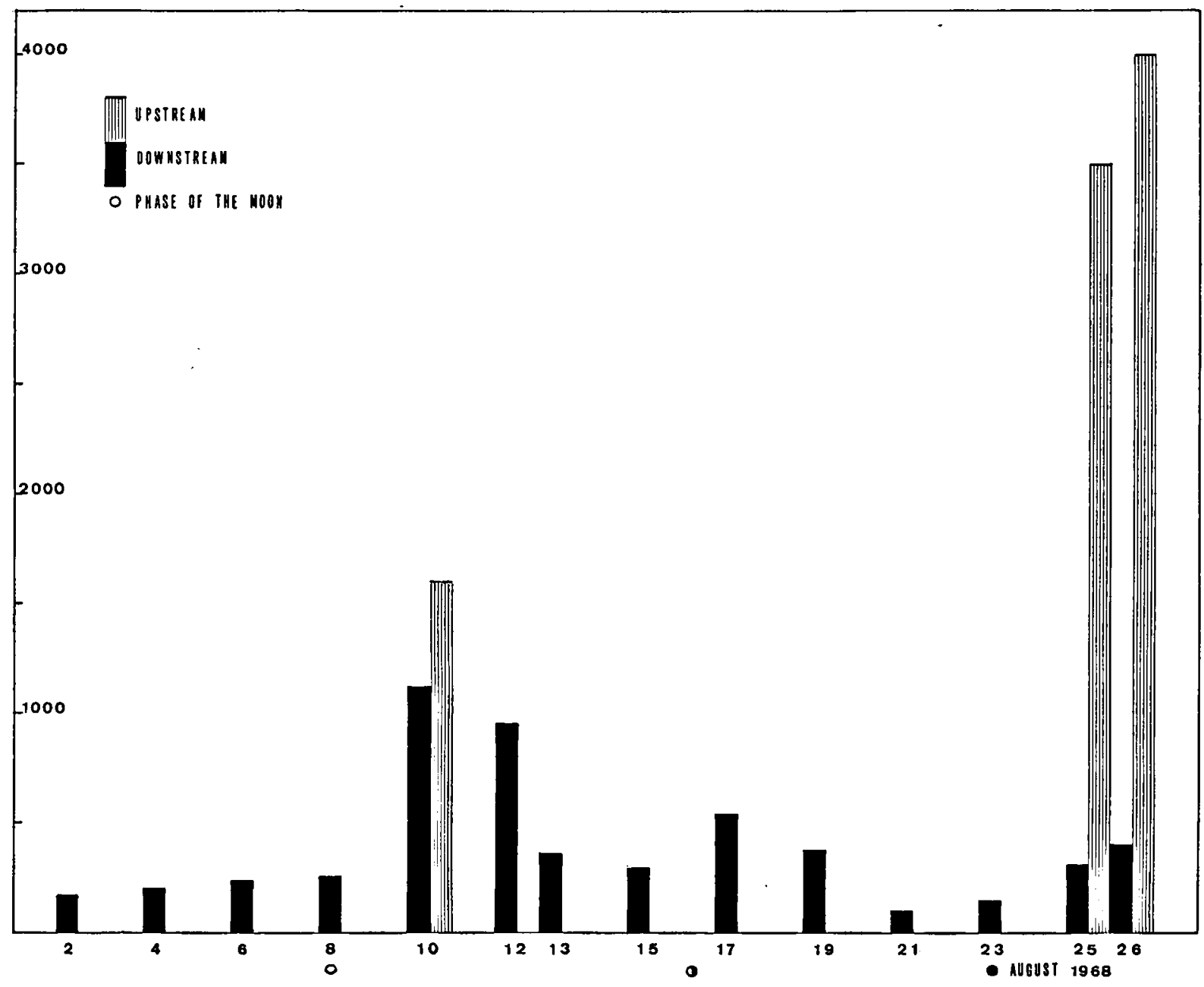

Fig. 16. Nocturnal catches of upstream and downstream migrants in Aug. 1968. Note that downstream migration takes place every night (and that the number of downstreamers apparently has little relation to the moon-phase or lightintensity), whereas upstream movements are limited to the periods of spring tides (i.e., about 2 days after new and full moon).

drifting animals, but he worked in a rivulet of only $25 \mathrm{~cm}$ deep.

The number of animals found in a "good" night in the drift net on Station I varies between 1000 and 1500. This would mean that at least 20,000 to 30,000 individuals, migrating downstream, crossed the imaginary section of the river at that Station.

\section{2) Upstream migrants}

During the few days that upstream migration takes place (viz., around H.W.S.), the number of animals that participate in this kind of activity is many times larger than that migrating downstream (cf. figs. 16-19, table IV). Numbers as high as 6,000 specimens per net per night have been observed (corresponding, according to the calculations explained in the previous paragraph, with some 120,000 individuals crossing, in upstream direction, the imaginary section of the river at Station I). The number of migrants in one net per hour may be as high as 4,000 .

\section{COMPOSITION OF THE SAMPLES}

All samples collected in the driftnet have been separated into juveniles, males, and females and all specimens have been measured. With the aid of these 
data, the following three questions can be answered:

(1) what is the composition of the samples captured;

(2) is there a difference between upstream and downstream migrants in one sampling station at any particular sampling time;

(3) is there a difference between samples collected at different sampling stations.

From the composition of the samples throughout the year, it is apparent that one complete reproductive cycle is completed per year.

It is clear (see table IX and fig. 20) that ovigerous females appear in the population in early December, and disappear in April and May. In the same two months, April and May, there is a strong rise in the percentage of juveniles in the net catches. These data will be discussed more fully in a following chapter, $\$$ XIV.

The answer to question 2 is more complex. Statistically, the composition of upstream and downstream migrants caught in the nets at Station I have been tested. (For way of measuring and testing, see $\$$ III.4). The test has been applied on samples collected on 5 Sep., 3 Oct. and 1 Dec. 1967 and on 29 Apr. 1968. In two of these, $5 \mathrm{Sep}$. and $1 \mathrm{Dec}$, the upstreamers differed significantly in size from the downstreamers. (significance 99\%, infinite number of degrees of freedom). In the remaining samples (3 Oct. and 29 Apr.) no significant differences existed between upstream and downstream migrants (cf.fig. 21).

Table IX contains amongst others the mean cephalic length in mm of animals caught at three different Stations (the material from Stations II and IV, that are only $30 \mathrm{~m}$ apart, has been pooled for this purpose in one column of the table; the greater part of the samples were collected at Station II, only those marked with an asterisk came from Station IV).

Only in one instance (28 Feb. 1968), the upstreamers are larger than the downstreamers. In all other cases, both have the same length, or the upstreamers are smaller than the downstreamers. The exceptional situation of $28 \mathrm{Feb}$. is puzzling, but may be explained on the one side by a statistical uncertainty since the number of individuals caught and measured was fairly small $(n=46)$, on the other hand it is influenced no doubt by the high percentage of ovigerous females migrating downstream on that day. For, the smaller size of females, when present in large numbers, have a lowering effect on the mean length of the total sample.

However this may be, the most interesting fact emerging from table IX is that during autumn and spring equinoxal spring-tides, just when the upstream

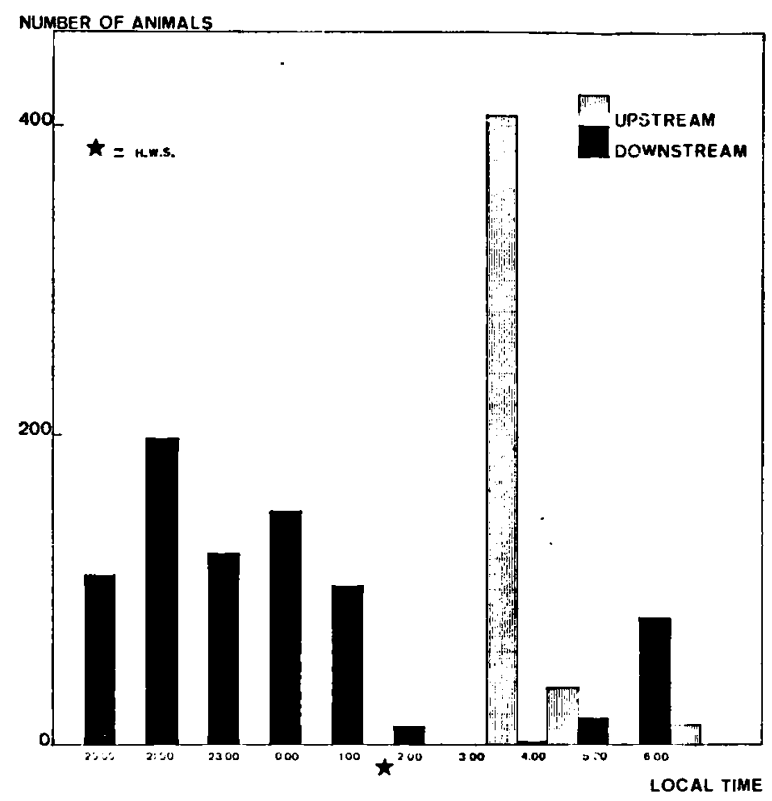

Fig. 17. Hourly catches of upstream and downstream migrants in the night of 21 to 22 Sep. 1967. Sunset at $18.51 \mathrm{~h}$, sunrise at $06.16 \mathrm{~h}$. Moonrise at $19.52 \mathrm{~h}$. Station I.

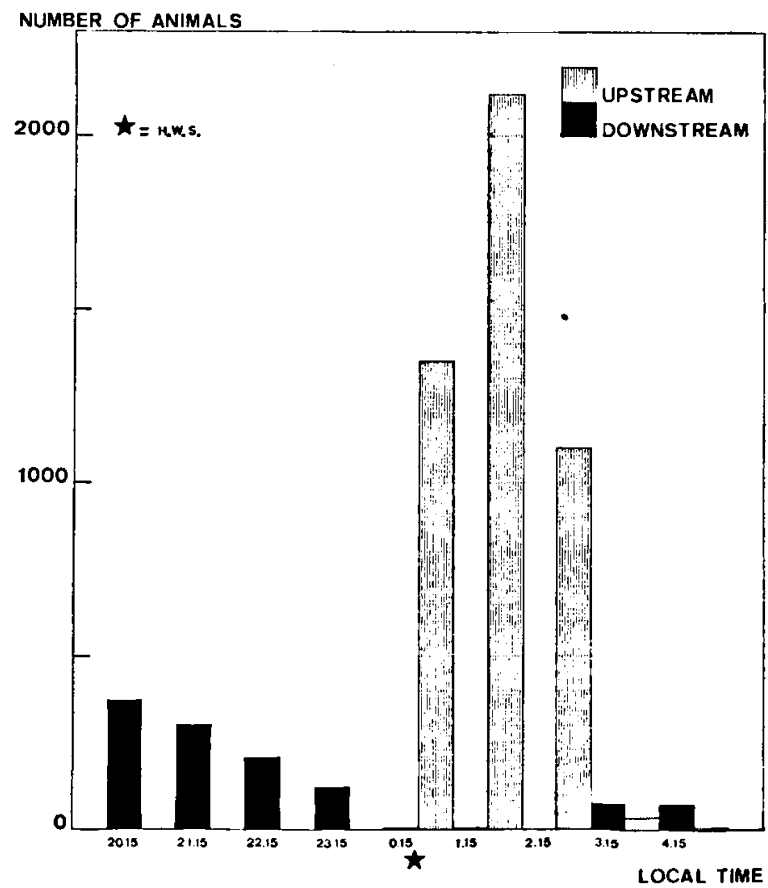

Fig. 18. Hourly catches of upstream and downstream migrants in the night of 4 to 5 Oct. 1967. Sunset at $18.22 \mathrm{~h}$, sunrise at $06.37 \mathrm{~h}$. Setting of the moon $18.44 \mathrm{~h}$. Station I. 
migration is most pronounced, the animals involved in this migration have the smallest size.

When we consider table IX, we can conclude that there is a clear difference between the downstreamers of Station III and those of the other Stations. The downstream migrants of Station III (the Rivière de Bazinghen, thus the most upstream Station) have a smaller size and the percentage of ovigerous females is usually lower than at the other Stations.

It is particularly clear from table $\mathrm{X}$, that the more upstream, the higher the percentage of juveniles in each population sample. This table shows the composition of dip-net catches taken at some $300 \mathrm{~m}$ interval along a stretch of nearly $2 \mathrm{~km}$ long of the Rivière de Bazinghen. Although the size shows rather considerable fluctuations, the percentages juveniles participating in the total catch rises rapidly from $38 \%$ (at the junction of the river with the Slack) to 93\% (nearly $2 \mathrm{~km}$ upstream of the mouth). That the size may vary irrespective of the juvenile morphology is shown also in one of the preceding chapters, $\$ \mathrm{~V}$. Although small size is always an indication of sexual immaturity, medium-large individuals still can be immature.
Table VIII. Advance of salty bottom water in the River Slack and its estuary at H.W.S. on 8 September 1967. Localities arranged from West (= most seaward) to East (= most inland).

\begin{tabular}{|l|c|}
\hline locality & chlorinityin \%o \\
\hline pools in estuary & 15.8 \\
Slack at Station I & 16.9 \\
Slack near bridge in village Slack & 1.68 \\
300 m East of former locality & 0.050 \\
junction of rivers Slack and Laronville & 0.075 \\
200 m East of this junction & 0.046 \\
junction of rivers Warem and Laronville & 0.076 \\
\hline
\end{tabular}

\section{DEPOPULATION OF UPSTREAM AREAS}

The only period with large upstream migration is, as we have shown before, the period of September through December. During the rest of the year downstream drift dominates. Of course, when downstream migration takes place every night, without sufficient repopulation by upstreamers, the upper reaches of the distributional area of G.zaddachi must depopulate to a certain extent. That this theoretical assumption holds true in nature can be easily shown by dip-net

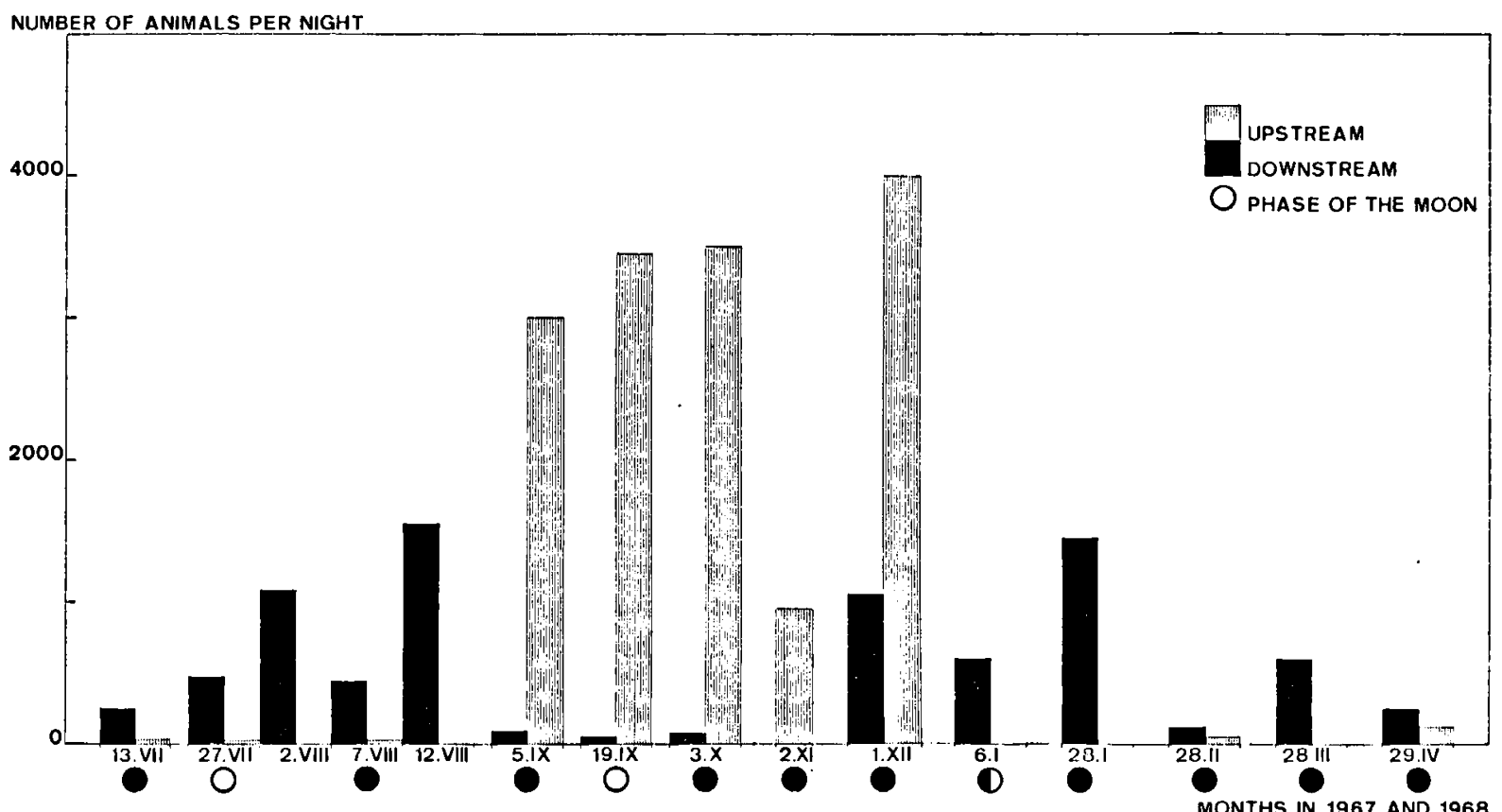

Fig. 19. Numbers of upstream and downstream migrants taken at Station I per net per night in the period 13 July 1967 to 29 April 1968. 


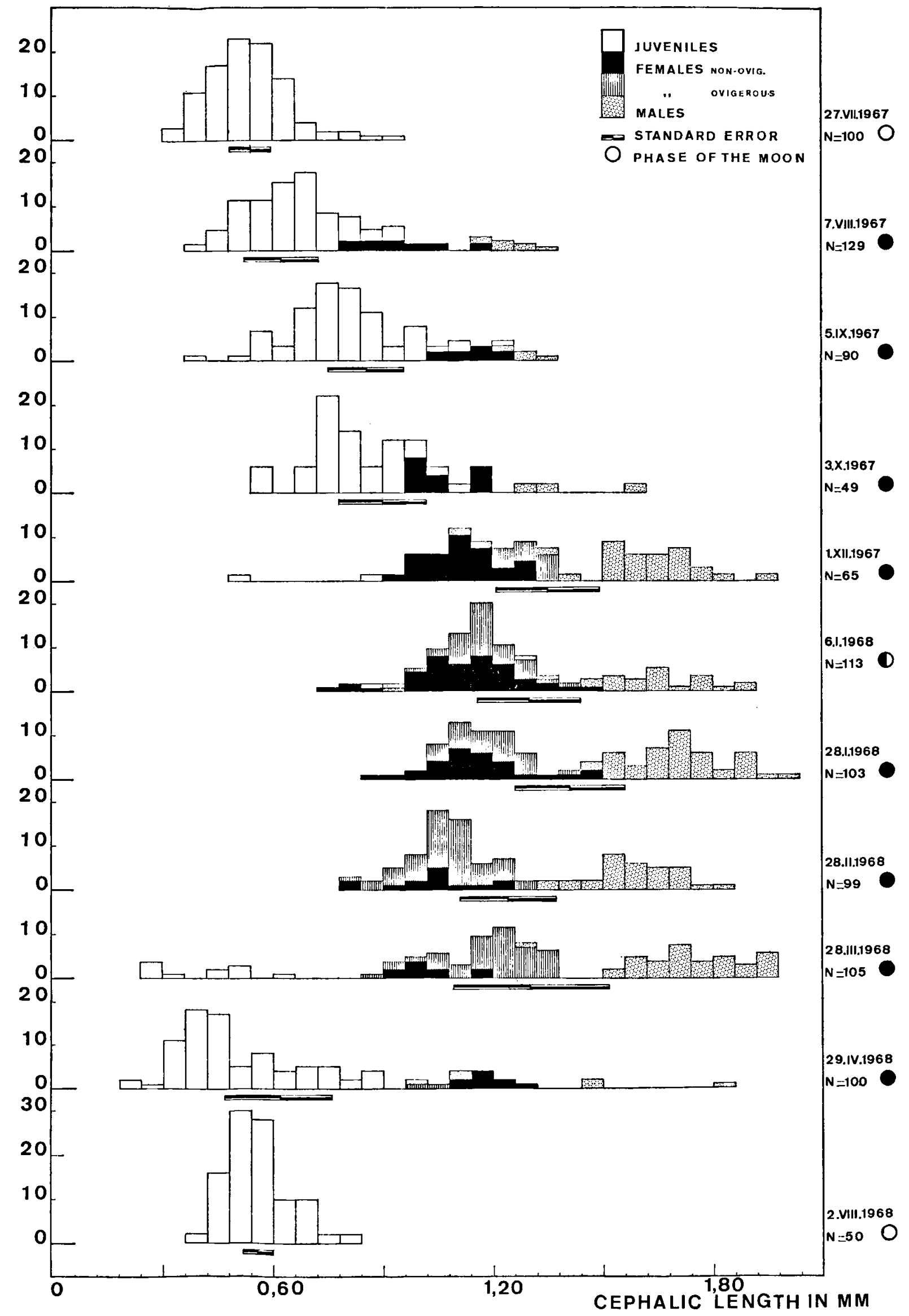

Fig. 20. Population composition of downstreamers at Station I during the year. The mean cephalic length at every sampling date is indicated, as well as the standard deviation from that mean. Downloaded from Brill.com04/26/2023 11:21:44AM 
Table IX. Cephalic lengths, and percentages of females and juveniles, during an eight months' observation period at three stations in the Slack river system.

\begin{tabular}{|c|c|c|c|c|c|c|c|}
\hline \multirow{3}{*}{$\begin{array}{c}\text { date } \\
\text { (day, month, year) } \\
\text { 5-IX-1967 }\end{array}$} & & \multicolumn{2}{|c|}{ Station I } & \multicolumn{2}{|c|}{ Station II } & \multicolumn{2}{|c|}{ Station III } \\
\hline & & upstream & downstream & upstream & downstream & upstream & downstream \\
\hline & $\begin{array}{l}1 \\
2 \\
3\end{array}$ & $\begin{array}{l}0.764(258) \\
0 \\
84\end{array}$ & $\begin{array}{l}0.860(90) \\
0 \\
84\end{array}$ & \multicolumn{2}{|c|}{ no catch } & \multicolumn{2}{|c|}{ no catch } \\
\hline 19-IX-1967 & $\begin{array}{l}1 \\
2 \\
3\end{array}$ & $\begin{array}{l}0.870(112) \\
0 \\
95\end{array}$ & $<$ & $\begin{array}{l}0.755(100) \\
0 \\
94\end{array}$ & $\begin{array}{l}0.947(105) \\
4 \\
70\end{array}$ & $\begin{array}{l}< \\
<\end{array}$ & $\begin{array}{l}0.825(100) \\
3 \\
88\end{array}$ \\
\hline 3-X-1967 & $\begin{array}{l}1 \\
2 \\
3\end{array}$ & $\begin{array}{l}0.963(99) \\
0 \\
80\end{array}$ & $\begin{array}{l}0.901(49) \\
0 \\
81\end{array}$ & $\begin{array}{l}0.860(110) \\
0 \\
87\end{array}$ & $\begin{array}{l}1.113(50) \\
0 \\
54\end{array}$ & $\begin{array}{l}0.843(110) \\
0 \\
89\end{array}$ & $\begin{array}{l}0.869(100) \\
0 \\
91\end{array}$ \\
\hline 1-XII-1967 & $\begin{array}{l}1 \\
2 \\
3\end{array}$ & $\begin{array}{l}0.990(74) \\
0 \\
62\end{array}$ & $\begin{array}{l}1.347(65) \\
17 \\
3\end{array}$ & $\begin{array}{l}1.091(100)^{\circ} \\
0^{\circ} \\
41^{\circ}\end{array}$ & $\begin{array}{l}1.455(65) \\
0^{\circ} \\
0^{\circ}\end{array}$ & \multicolumn{2}{|c|}{ no catch } \\
\hline 6-I-1968 & $\begin{array}{l}1 \\
2 \\
3\end{array}$ & $<$ & $\begin{array}{l}1.239(113) \\
30 \\
2\end{array}$ & \multicolumn{2}{|c|}{ no catch } & $\begin{array}{l}< \\
<\end{array}$ & $\begin{array}{l}1.308(87) \\
46 \\
1\end{array}$ \\
\hline 28-I-1968 & $\begin{array}{l}1 \\
2 \\
3\end{array}$ & $\begin{array}{l}< \\
<\end{array}$ & $\begin{array}{l}1.409(100) \\
49 \\
0\end{array}$ & $\begin{array}{l}1.365(91) \\
8 \\
3\end{array}$ & $\begin{array}{l}1.332(99) \\
50 \\
0\end{array}$ & $\begin{array}{l}1.212(105) \\
15 \\
11\end{array}$ & $\begin{array}{l}1.265(100) \\
39 \\
1\end{array}$ \\
\hline 28-II-1968 & $\begin{array}{l}1 \\
2 \\
3\end{array}$ & $\begin{array}{l}1.450(46) \\
23 \\
4\end{array}$ & $\begin{array}{l}1.241(99) \\
24 \\
0\end{array}$ & $<$ & $\begin{array}{l}1.391(90) \\
31 \\
0\end{array}$ & $<$ & $\begin{array}{l}1.257(88) \\
25 \\
0\end{array}$ \\
\hline 28-III-1968 & $\begin{array}{l}1 \\
2 \\
3\end{array}$ & $\begin{array}{l}< \\
<\end{array}$ & $\begin{array}{l}1.305(105) \\
43 \\
11\end{array}$ & $\begin{array}{l}1.097(82)^{\circ} \\
37^{\circ} \\
32^{\circ}\end{array}$ & $\begin{array}{l}0.767(100)^{\circ} \\
1^{\circ} \\
62^{\circ}\end{array}$ & & catch \\
\hline 29-IV-1968 & $\begin{array}{l}1 \\
2 \\
3\end{array}$ & $\begin{array}{l}0.533(90) \\
3 \\
96\end{array}$ & $\begin{array}{l}0.620(100) \\
2 \\
84\end{array}$ & $<$ & $\begin{array}{l}< \\
<\end{array}$ & $<$ & $\begin{array}{l}< \\
<\end{array}$ \\
\hline
\end{tabular}

$1=$ mean cephalic length in $\mathrm{mm}$ (sample size mentioned in parentheses).

$2=$ percentage of ovigerous females.

$3=$ percentage of juveniles.

= data from Station IV (see text $\$ \mathrm{X}$ ).

$<=$ sample size too small for statistical treatment.

sampling: in late summer, thus just before the beginning of the autumn upstream migration wave, the uppermost $1500 \mathrm{~m}$ of the area inhabited in winter by G.zaddachi is entirely depopulated. Thus, in the winter, G.zaddachi populates the Rivière de Bazinghen to $1150 \mathrm{~m}$ upstream of its junction with La Fausse Rivière; in summer, the distribution boundary of G.zaddachi lies $350 \mathrm{~m}$ downstream of that junction.
The depopulated area is temporarily colonized by the fresh-water species, Gammarus pulex (L.) and Echinogammarus berilloni (Catta).

This results in a picture in which G.zaddachi abandons in the warmer summer months the most upriver reaches of its area, a picture that is in good agreement with Kinne's $(1952,1953)$ observation that Gammarus can stand lower salinities better at lower 
temperatures (in other words, that its osmoregulatory performances are better at lower temperatures).

\section{MIGRATION DISTANCE PER NIGHT}

\section{1) Downstream migration}

Large numbers of individuals taken at night in a downstream driftnet at Station IV were tagged. These were released at 4 consecutive days in June 1967. A first group was released at position $\mathrm{A}$, at $5 \mathrm{~m}$ distance upstream of a driftnet, blocking the entire brook. A second group was released at position B, at $50.50 \mathrm{~m}$, a third group at position $\mathrm{C}$, at $66.50 \mathrm{~m}$, and a fourth group at position $\mathrm{D}$, at $81.00 \mathrm{~m}$ upstream of the net (see fig. 22). The distances between the points of release and the net were determined only by the nature of the river. Thus, the somewhat illogical figures of $5.00 \mathrm{~m}, 50.50 \mathrm{~m}, 66.50 \mathrm{~m}$, and $81.00 \mathrm{~m}$ have been obtained.

In addition to a net for catching downstream migrants among the released animals, also a net for upstream migrants was placed, always $10 \mathrm{~m}$ upstream of the place of release.

The results are shown in table XI.

From the table, several conclusions can be drawn:

(1) If we total all the experiments, 548 tagged individuals (or nearly 35\%) have been recaptured. These numbers are sufficient important to warrant also the conclusions (2) to (5).

(2) Nearly $50 \%$ of the tagged animals have migrated

Table X. Percentages of iuveniles and mean cephalic length in the Rivière de Bazinghen, beginning with the most seaward ending with the most inland locality ( $n=$ sample size).

\begin{tabular}{|c|rrr|}
\hline locality & \% juv. $\begin{array}{c}\text { mean } \\
\text { cephalic } \\
\text { length }\end{array}$ & n \\
\hline $\begin{array}{l}\text { Junction Slack/Rivière de } \\
\text { Bazinghen }\end{array}$ & 38 & 1.016 & 100 \\
$\begin{array}{l}\text { Riv. de Bazinghen, S. of } \\
\text { La Parthe }\end{array}$ & 49 & 1.010 & 100 \\
$\begin{array}{l}\text { Riv. de Bazinghen, SE. of } \\
\text { La Parthe } \\
\begin{array}{c}\text { Riv. de Bazinghen, S. of } \\
\text { Otove }\end{array}\end{array}$ & 54 & 1.085 & 103 \\
$\begin{array}{l}\text { Riv. de Bazinghen, junction } \\
\text { with Ruisseau d'Otove } \\
\text { Riv. de Bazinghen, junction } \\
\text { with Fausse Rivière }\end{array}$ & 70 & 1.117 & 50 \\
\hline
\end{tabular}

over 5.00 and more than $50 \mathrm{~m}$, respectively, in one night.

(3) The percentage of recaptures drops sharply, when the tagged individuals are released at more than $50 \mathrm{~m}$ from the net.

(4) No individual has travelled $81 \mathrm{~m}$ per night.

(5) No individual has migrated $10 \mathrm{~m}$ upstream. ${ }^{1}$ )

Of course, the nets contained, in addition to the tagged individuals, also considerable numbers of unmarked specimens (ratio marked-unmarked specimens about $1: 4.1$ ).

The current velocity at Station IV during these experiments was $40-50 \mathrm{~cm} / \mathrm{sec}$. (this is $24 \mathrm{~m} / \mathrm{min}$., or $1440 \mathrm{~m} / \mathrm{h}$.). If the transport was purely passive (= accidental), much greater distances than $67 \mathrm{~m}$ would have been covered.

Conclusion. - The downstream migration during one night often amounts to more than $50 \mathrm{~m}$, but never reaches a distance of $81 \mathrm{~m}$.

\section{2) Upstream migration}

An experiment comparable with that described in the previous paragraph, was also executed at Station I. This experiment is described in detail in the next section ( $\$$ XIII). From this experiment it can be concluded that a certain percentage of the upstream migrants can cover distances of at least $60 \mathrm{~m}$ in one night.

Thus, there is no great difference in the upstream and downstream migration distance, both being in the order of $50-60 \mathrm{~m}$ for at least a major part of the animals.

\section{ACCIDENTAL VERSUS ACTIVE TRANSPORT}

The fact that upstreamers and downstreamers both make use of the water currents (see $\$$ VII) and that there are not always significant size differences between the two groups of migrants (see $\S \mathrm{X}$ ) could be an indication that the observed movements of members of the population of G.zaddachi support entirely upon accidental, passive, transportation along with the currents during their nocturnal activity (feeding) period.

There are a couple of facts that prove convincingly that accidental, passive, transport is out of question,

1) It must be borne in mind that the individuals used in this tagging experiment were originally caught during downstream migratory activity, thus hardly show any tendency to migrate upstream (see also $\$$ XIII). 
Table XI. Distances covered in one night by tagged individuals.

\begin{tabular}{|c|ccc|cc|}
\hline & \multicolumn{2}{|c|}{ DOWNSTREAMERS } & \multicolumn{2}{c|}{ UPSTREAMERS } \\
$\begin{array}{c}\text { Number of } \\
\text { individuals } \\
\text { tagged }\end{array}$ & $\begin{array}{c}\text { distance to } \\
\text { downstream } \\
\text { net (in m) }\end{array}$ & $\begin{array}{c}\text { number } \\
\text { recaptured }\end{array}$ & $\begin{array}{c}\text { percentage } \\
\text { recaptured }\end{array}$ & $\begin{array}{c}\text { distance to } \\
\text { upstream } \\
\text { net (in m) }\end{array}$ & $\begin{array}{c}\text { number } \\
\text { recaptured }\end{array}$ \\
\hline 550 & 5.00 & 212 & 47 & 10.00 & 0 \\
550 & 50.50 & 290 & 52 & 10.00 & 0 \\
389 & 66.50 & 46 & 12 & 10.00 & 0 \\
94 & 81.00 & 0 & 0 & 10.00 & 0 \\
\hline
\end{tabular}

Table XII. Surface water temperatures in the Slack system.

\begin{tabular}{|c|c|c|c|}
\hline locality & $\begin{array}{c}\text { date } \\
\text { (day, month, year) }\end{array}$ & $\begin{array}{l}\text { temp. } \\
\text { in }{ }^{\circ} \mathrm{C} \text {. }\end{array}$ & remarks \\
\hline $\begin{array}{l}\text { Ruisseau de Warem (Stat. IV) } \\
\text { Ruisseau de Warem (Stat. IV) } \\
\text { Slack (Stat. I) } \\
\quad \text { do. } \\
\text { Slack (Stat. I) } \\
\quad \text { do. } \\
\text { Riv. de Bazinghen (Stat. III) } \\
\text { Slack (Stat. I) } \\
\text { Slack (Stat. I) } \\
\text { Riv. de Bazinghen (Stat. III) } \\
\text { Junction Slack/Laronville } \\
\text { Ruisseau de Warem (Stat. IV) } \\
\text { Junction Slack/Laronville } \\
\text { Riv. de Bazinghen (Stat. III) } \\
\text { Junction Slack/Laronville } \\
\text { Slack (Stat. I) }\end{array}$ & $\begin{array}{l}\text { 13-V-1967 } \\
20-V I I-1967 \\
5-\text { III-1967 } \\
\text { do. } \\
\text { I1-VIII-1967 } \\
\text { do. } \\
22-I X-1967 \\
2-X I-1967 \\
1-X I I-1967 \\
5-I-1968 \\
30-I-1968 \\
30-I-1968 \\
27-I I-1968 \\
31-I I I-1968 \\
1-V-1968 \\
20-\text { VIII-1968 }\end{array}$ & $\begin{array}{r}13.1 \\
18.2 \\
18.6 \\
17.1 \\
18.2 \\
16.2 \\
14.5 \\
10.9 \\
8.1 \\
7.5 \\
6.5 \\
6.5 \\
3.5 \\
12.0 \\
13.0 \\
17.3\end{array}$ & $\begin{array}{l}\text { day } \\
\text { day } \\
\text { day } \\
\text { night } \\
\text { day } \\
\text { night } \\
\text { night } \\
\text { night } \\
\text { night } \\
\text { day } \\
\text { day } \\
\text { day } \\
\text { day } \\
\text { night } \\
\text { day } \\
\text { day }\end{array}$ \\
\hline
\end{tabular}

thus that the observed movements support on an active, behaviour pattern, being part of the population dynamics of G.zaddachi.

These proofs are the following:

(1) Of the 15 species inhabiting the river Slack and its estuary, all show nocturnal activity, but only G.zaddachi participates in migratory movements.

(2) Upstream migration of G.zaddachi is important during the equinoxal H.W.S. of the autumn, but during the spring equinoxal H.W.S., when also current reversal is observed, hardly any upstream migration takes place (see fig. 19).

(3) If transport was purely passive, the distance covered by downstreamers during one night would be much larger than it actually is (see $\$$ XII.I).

(4) Final proof was obtained by the following experiments:

Tagging experiment 5-6 Oct. 1967. Station I. Marked red were 1000 specimens caught the night before in an upstream net - thus specimens being in the (physiological) phase of migrating up-river -, and marked white 116 specimens caught the night before in a downstream net (thus in a "down-river mood"). The red specimens were released at $17.00 \mathrm{~h}$. on 5 Oct., during the reflux of the tide, thus during a period in which there is a strong current in seaward direction. The white specimens were released at $23.15 \mathrm{~h}$. on 5 Oct., during the current reversal. Consequently the red specimens (those "in the mood" of migrating up-river) were released at a period of downriver currents, the white specimens (those "in the mood" of drifting down-river) during a period of upriver currents. Two upstream nets were placed, upstream of the release places (see fig. 23 for position of nets and release places). Both nets were lifted at $02.00 \mathrm{~h}$. on 6 Oct. Both nets contained a number of red specimens (25 specimens, or $2 \frac{1}{2} \%$ recaptured in both nets together); part of the red specimens had migrated upstream over a distance of $60 \mathrm{~m}$ to reach the net. No white specimens were recaptured. 


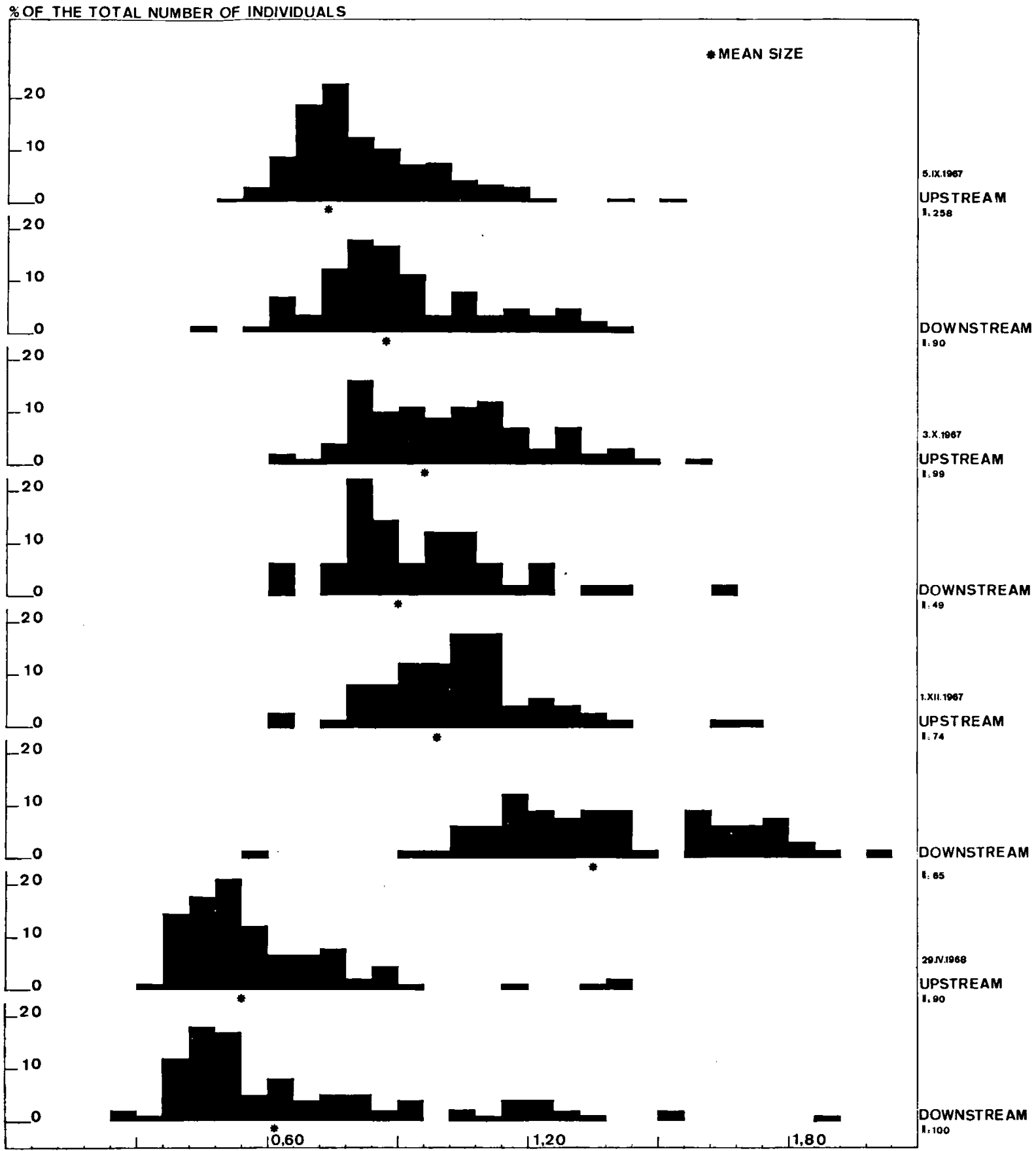

CEPHALIC LENGTH IN MM

Fig. 21. The cephalic lengths at different dates in upstreamers and downstreamers caught at Station $\mathrm{I}$. $(\mathrm{N}=$ size of sample) 


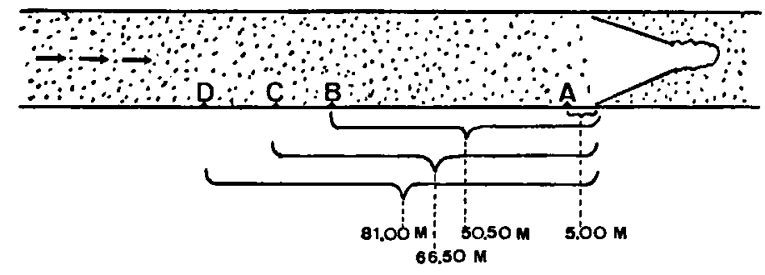

Fig. 22. Position of drift net and points of release of tagged individuals at Station IV. Distances indicated in meters. Arrows indicate the direction of the stream. Explanation see $\$$ XII. 1.

A second, more or less comparable, experiment was done on 1-2 Dec. 1967. Marked red were 1730 animals caught in the upstream net the night before, marked blue were 570 specimens caught in the downstream net the night before. Upstream of the release place, a combination net (for both upstream and downstream captures, see figs. 4-5) was installed, downstream of the release place, a downstream net was installed (see fig. 24). During a period of normal, seaward, river flow, at $16.45 \mathrm{~h}$. on $1 \mathrm{Dec}$., the red specimens were released. During a period of current reversal, at $22.45 \mathrm{~h}$. on $1 \mathrm{Dec}$., the blue specimens were released.

In the combination net, thus upstream of the release place, 21 red and 2 blue specimens were recaptured. In the downstream net, placed down-river of the release place, one blue and no red individuals have been recaptured.

The conclusion from these two experiments is obvious: animals physiologically in the catadromous phase, continue after tagging, and irrespective of the direction of the stream at the moment of release, migrating up-river, whereas animals with an anadromous physiological orientation continue migrating down-river.

The upstreamers have had more than 6 hours, mostly moreover in the dark, to move (actively or passively) down-river, but they did move actually 40 to $60 \mathrm{~m}$ up-river. Not a single upstreamer ever entered in a down-river net.

\section{THE ANNUAL CYCLE}

\section{1) Introduction}

Kinne (1952) showed that the lifespan of Gammarus zaddachi is restricted to a period of 12 to 16 months. To check Kinne's observation for the situation found in the river Slack, a number of individuals from each samples was measured (see: $\$$ III.4), sorted into juveniles and adults, whereas the last-named category was sexed. The maximum and minimum sizes in each sample, the mean cephalic length for each category ( $\delta$, + , or juv.) for each sample, the percentage of each category per sample, and the standard deviations, have been recorded. Lists containing these data have been deposited in the Zoological Museum of the University of Amsterdam and are available for inspection to every scientist interested in them. Some of the more pertinent data have been used also in table IX.

\section{2) The situation at Station I}

In fig. 20, the data for down-river migrants have been plotted, caught at Station I. Station I has been selected purposely for this subject, since it is the most down-river Station, and one might expect in the
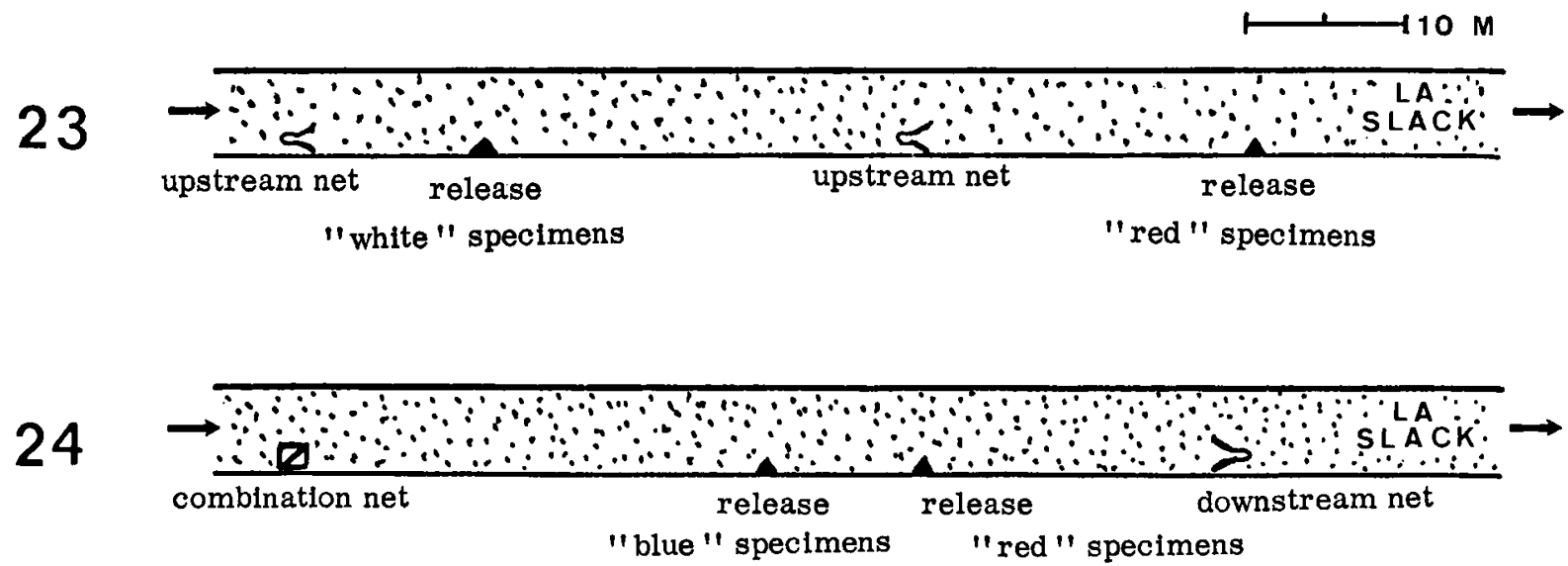

Figs. 23-24. Position of nets, etc. in the tagging and recapture experiments, described in $\$$ XIII (4). The arrows indicate the direction of the normal (= seaward) stream in the river. 
catches not only those animals that lived near Station I, but also those migrating down-river from more upstream localities.

On 27 July 1967 (fig. 20, top) the down-river migrants consist entirely of juveniles (open blocks in the graphs). On 7 July 1967, the first adult females (black blocks) and adult males (stippled blocks) appear. The first ovigerous females appear in the catches on $1 \mathrm{De}-$ cember 1967 (hatched blocks); at this date hardly any juveniles are present any more. Juveniles are entirely absent in the catches from 6 January to 28 February 1968, they reappear again at 28 March 1968. On 29 April 1968 the juveniles form already the greater part of the catch and on 2 August 1968 the entire catch is composed of juveniles. Thus we see that ovigerous females occurred at Station I from $1 \mathrm{De}-$ cember 1967 to 29 April 1968, juveniles from 27 July 1967 (start of observation period) to 1 December 1967, and again, from 28 March 1968 to 2 August 1968 (end of observation period). Along with this shift in composition of the catches, the mean length (= mean cephalic length of the entire sample measured, $\mathbf{n}$ being usually about 100) shows an increase from July to November 1967, remains fairly constant during winter, and decreases suddenly in April 1968 (see fig. 20, the mean length and standard deviation being indicated under the graph of every date).

The reproduction period (December till April) is in good agreement with Kinne's data, as well as a lifespan of 1 year (as demonstrated by the absence of adults in summer). Also in good agreement with Kinne's report (1952) is the sex-ratio, which - in the reproduction period - was 1 of per $1.92 \%$ in the Slack, versus 1 s per $2 q$ in the Bay of Kiel, Germany.

\section{3) The situation at the Stations II and III}

At Station I, the sex-ratio and the reproduction period were in reasonable agreement with the data obtained by Kinne in Germany. Station I showed at the same time the greatest resemblance to the German sampling area, in that both localities lie well within mixohaline waters (classification according to the Venice System). Stations II and III, however, lie in the fresh-water region of the stream.

The sex-ratio in these fresh Stations differs in autumn from that in Station I: in Station I all year round there are 1.5 to 2 times as many females as males; in autumn at the fresh Stations there are more males (sometimes $6.5 \times$ so many) than females. Later in the year, when the reproduction period starts, the ratio shifts again in the advantage of the females, and stays close to the $q: \delta$ ratio of $2: 1$.
Two possible explanations of this observation (too low a percentage of females in autumn at the fresh Stations) can be brought forward:

(1) Males grow faster than females, obtain earlier their adult morphology, thus their sex could be properly recognized earlier than that of the females which were classified longer with the category unsexed juveniles.

This explanation fails to explain why at Station I, where the same method of classifying into the categories juvenile-female-male was used, no anomaly in the autumn sex-ratio was found.

(2) This conclusion leads to a modification of statement (1), in that males in fresh-water attain earlier the adult morphology than fresh-water females.

Fig. 25 shows the appearance of ovigerous females at Stations I, II, and III, and the simultaneous reduction of the percentage of juveniles. From this figure, it is clear that in the period from July to November, the percentage of juveniles in the population gradually decreases from $100 \%$ to near 0\%. At Station I, ovigerous females appear already in the population in November, before the last juveniles disappeared (= moulted into an adult morph). At Stations II and III, there is a gap of 1 to 2 months between the disappearance of the last juvenile and the appearance of the first ovigerous females. In this lapse of time, the population consists of morphologically adult, but sexually inactive individuals. In the two fresh Stations (II and III), the reproduction period does not only start later, but also lasts shorter.

These phenomena are in agreement with Kinne's experimental work (1952), showing that in Gammarus duebeni and in G.zaddachi, at a temperature of $>$ $8^{\circ} \mathrm{C}$, the eggs developed best at a salinity of $10 \%$, whereas at lower temperatures the salinity did not influence any longer the development. The lower the temperature, the lower also the salinity at which females still can produce eggs. In Stations II and III, ovigerous females do not appear in the population until the temperature drops under a certain value. This limitating temperature value (above which no females get sexually mature any longer in fresh-waters) appears to lie in the Slack roughly at $7^{\circ} 5$ to $8^{\circ} 0 \mathrm{C}$. This value is obtained through comparison of the temperature values recorded in table XII and the time of appearance of ovigerous females, as plotted in fig. 25 . This limitating temperature value of $7^{\circ} 5-8^{\circ} 0$ is working both at the beginning of the reproduction period (retarding its start in fresh-water) as well as at the end of the reproduction period (accelerating the end of the egg production in fresh-water). 


\section{OVIG.}

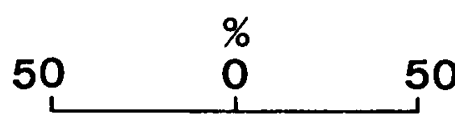

MAY

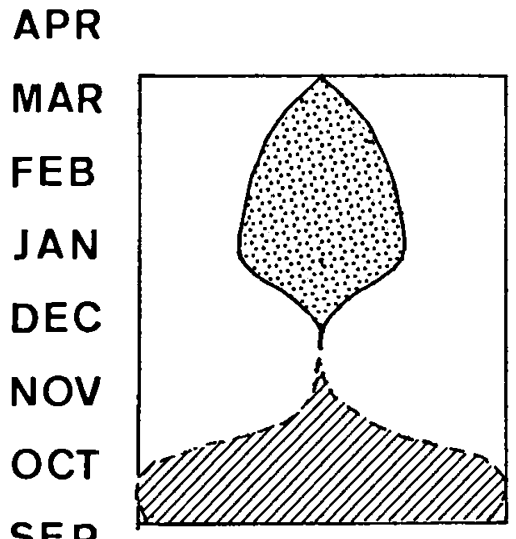

$A \cup G$

\section{JUVENILES}

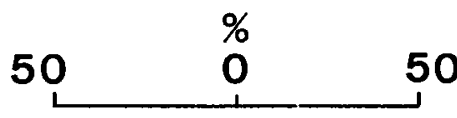

50

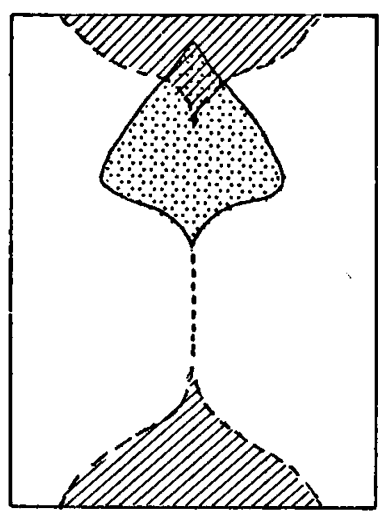

STATION II
REMAINING

ADULTS
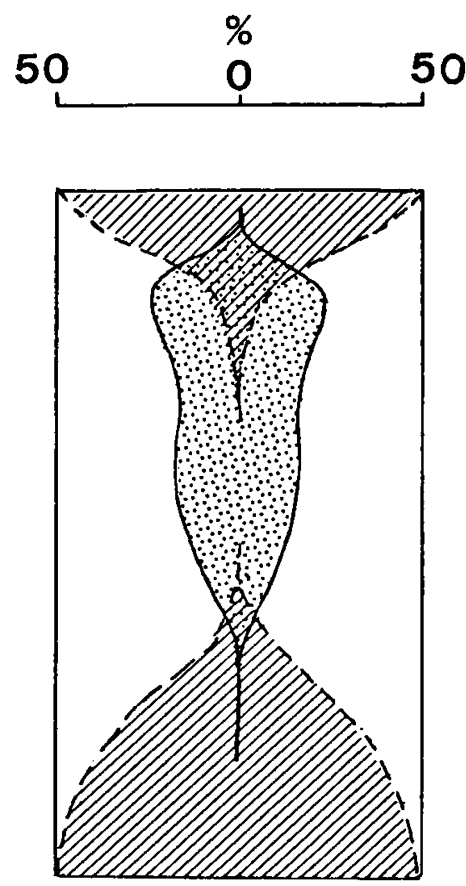

STATION I

Fig. 25. Composition of downstreamers at three different stations (Station $I$ is mixohaline, the other two are limnic). Explanation see $\$$ XIV. $3(2)$.

\section{4) Conclusion}

Ovigerous females show up first in the poikilohaline parts of the river in November. More up-river, in the permanently fresh region, ovigerous females appear 1 to 2 months later, probably only then when the water temperature falls under $7^{\circ} 5 \mathrm{C}$. In the freshwater region, the reproduction period not only starts later, but also lasts shorter.

\section{COMPARISON OF POPULATION HISTIO- GRAMS OF DIFFERENT YEARS}

In figs. 26-27 down-river migrants from the same dates in 1967 and in 1968 have been compared. The dates used for this comparison are 2 August, 1967 and 1968, and 12-13 August, 1967 and 1968. In both instances, the histiograms for 1967 show a greater mean length, and a higher percentage of morphological adults in the entire population than those for 1968. On the other hand, the composition of the drifters (as reflected by the length distribution) on 27 July 1967 (fig. 26, top) was almost identical to that on 2 August 1968 (fig. 26, bottom). This indicates that the growth in 1968 is one week slow as compared with that of 1967 . It is probable that this backlog can be explained by the fact that $1967 \mathrm{had}$ a fine, warm summer (probably favourable for a more rapid growth), whereas the summer temperatures in 1968 were below the mean.

\section{SYNTHESIS OF THE ANNUAL REPRO- DUCTIVE AND MIGRATORY CYCLE}

In the river Slack, the reproductive cycle is correlated with the migratory cycle. In autumn (September to November) when during the equinoxal tides current reversal is strong, mass repopulation of the up-river reaches takes place (see $\$$ VIII). During this period, the up-river migrants are of significantly smaller size than the down-river migrants $(\S \mathrm{X})$, their morphology 


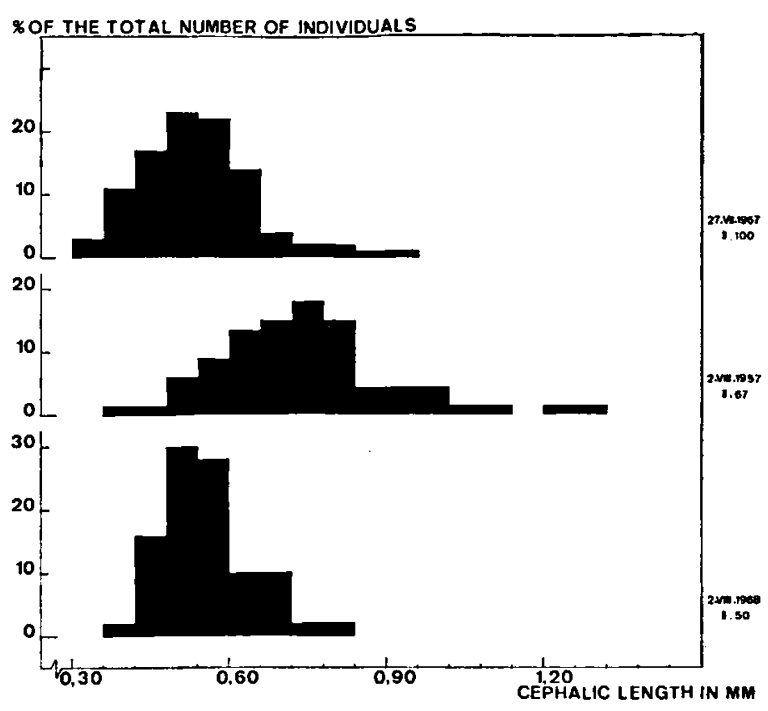

Fig. 26. Histiograms of the cephalic length of down-river migrants at three different dates. The lower two histiograms are based on catches at precisely one year interval. Explanation see $\S \mathrm{XV}$.

is the juvenile one. It must be concluded then, that the repopulation of the up-river reaches is performed by juvenile animals, assisted by the short period of current reversal ( $\$$ VII.1). It is a well-known fact that juveniles are more resistant to lower salinities than adults and can migrate farther up-stream than adults do (the flounder, Platichthys flesus, is a good example).

During the entire year, anadromous migration ("organic drift") takes place ( $\$$ VIII), during which a certain portion of the "standing crop" leaves its territory and migrates down-river. This all-year round down-river migration causes a depopulation of certain up-river regions that were populated in the fall ( $\$ \mathrm{XI})$. The down-stream migrants attain sexual maturity in winter ( $\$ \mathrm{XIV})$, first in the saltier, estuarine

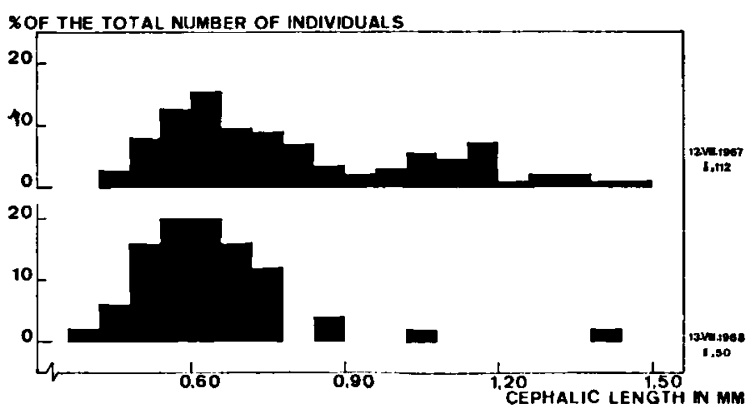

Fig. 27. Histiograms of the cephalic length of down-river migrants taken at one year interval. Explanation see $\$ \mathrm{XV}$. part of the river, later also - when the watertemperatures drop below roughly $7^{\circ} 5 \mathrm{C}$. - in the freshwater part of the river ( $\$$ XIV-3). The first juveniles are found late March, and during the rest of spring, the remaining adults gradually disappear to make place for the new generation ( $\$$ XIV.2). These juveniles stay down-river till next fall, when they migrate up-river again.

In agreement with previous observations by other authors ( $\$$ VI.1), the migratory activity is subject to a day-night-rhythm. Migration takes only place at night and reaches its maximum shortly after sunset for down-river migrants (see $\$$ VI.2) or during the period of current reversal for up-river migrants ( $\$$ VII.1). The migration is not accidental ( $\$$ XIII) animals that are physiologically in a catadromous phase do move up-river, irrespective of the direction of the current, and vice-versa. Moreover, other gam marid species in the area (14 species) do not show migratory activity.

Of course, the animals that live far up-river do not necessarily migrate to the sea-shore, but just a certain distance down-river. This distance may be close to $1500 \mathrm{~m}$, as is demonstrated by the depopulation of the uppermost $1500 \mathrm{~m}$ of the winter area $(\$ \mathrm{XII})$. The known migration distance per night, both of upstream migrants ( $\$$ XIII) and of downstream migrants $(\$ \mathrm{X} .1)$, is sufficient to explain the yearly migration cycle in the river Slack.

Of the population at any given section of the river (during daytime, the time of non-activity), a certain part (stippled in fig. 28) participates in the nocturnal migration activities. During certain periods of the year (fall, see fig. $28 \mathrm{~A}$ ) the percentage of animals participating in up-river migration dominates, in other periods (late winter, see fig. $28 \mathrm{~B}$ ) the down-river migrants are in the majority. In the up-river migration, chiefly juveniles participate, which is not astonishing, since the entire population chiefly consists of juveniles in early fall ( $\$$ XIV), whereas in spring and summer upstream areas are gradually depopulated through down-river migration of the up-growing juveniles, that - during their way down the river reach maturity and get ovigerous in the estuarine part of the river.

The idea of Waters, that overpopulation of the upriver reaches results in off-flow of part of the "standing crop" throughout the year is not confirmed for G.zaddachi in our study. First of all, G.zaddachi reproduces chiefly in the down-river, and not in the up-river reaches, and secondly the transport is tied to a physiological phase in the animal's developmental cycle. 


\section{AUTUMN}

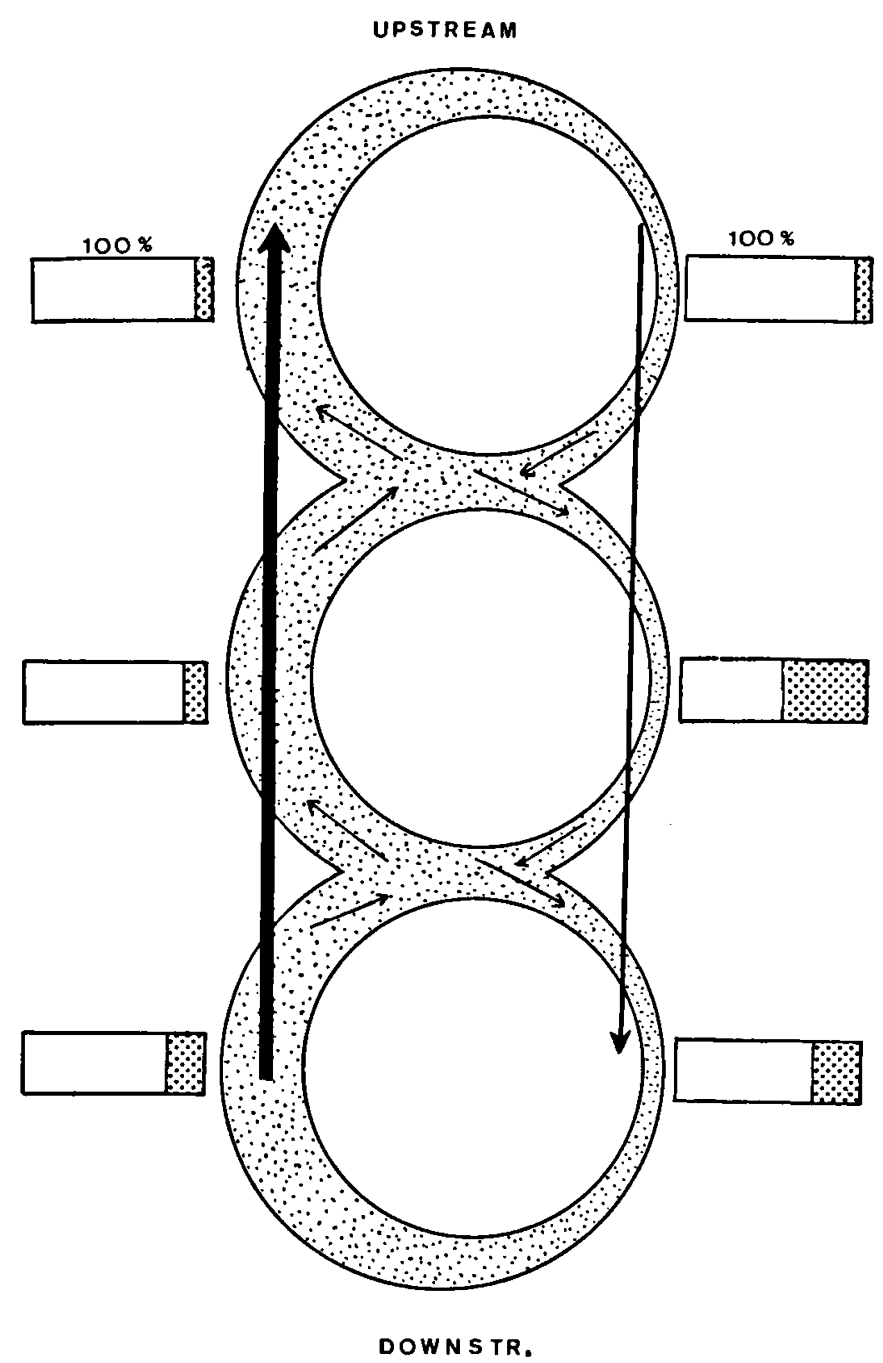

WINTER

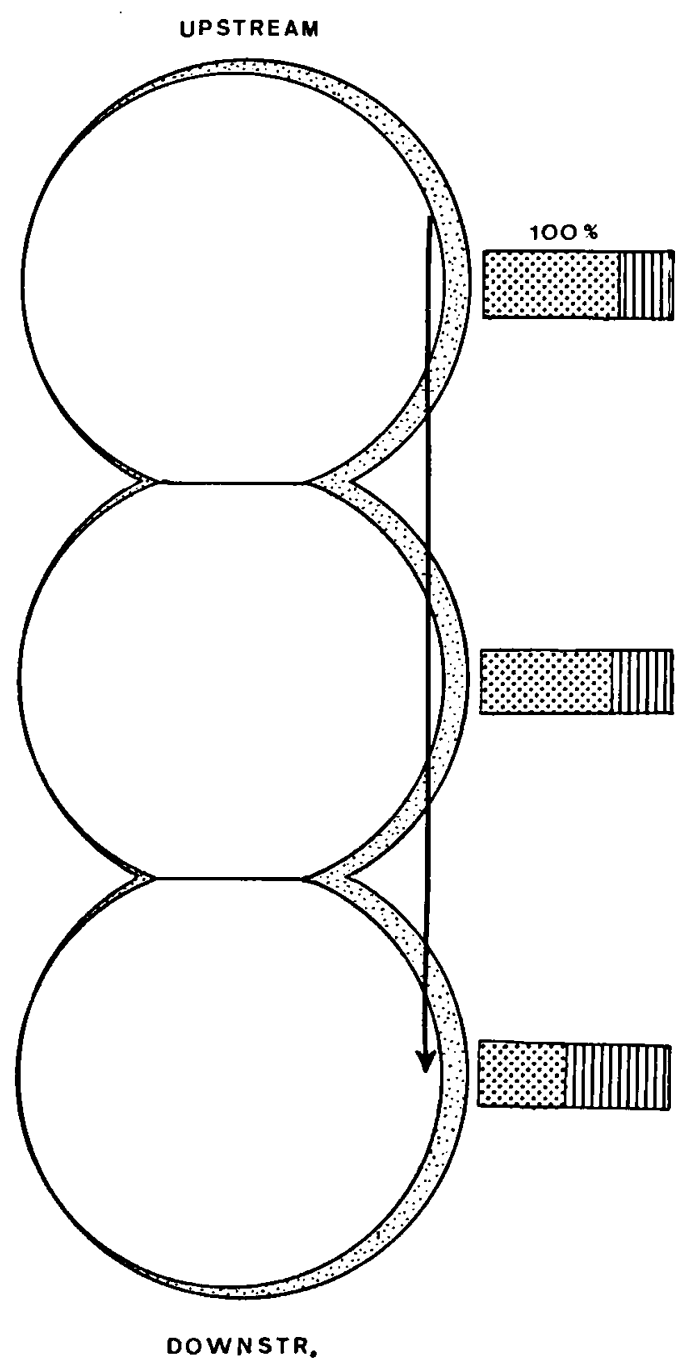

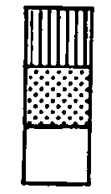

ovig. 9

o' + non - ovig. $?$

juveniles

Fig. 28. Diagrammatic representation of the migration pattern of Gammarus zaddachi in autumn (= early October) and in winter (= late February). The dotted circles indicate that portion of the total population participating in migratory activity. The arrows indicate the direction of this activity. The undotted part of the diagram represents the part of the population not participating at that moment in migratory activity.

The width of the dotted circles is an indication for the numbers of animals participating in migration.

For a complete migration diagram in the River Slack, a great number of overlapping circles should be imagined.

The blocks at both sides of the migration circles indicate the composition of the migrating population (ovigerous females, males plus non-ovigerous females, juveniles). 


\section{DISCUSSION}

As was shown in the preceding paragraphs, the activities of Gammarus zaddachi are greatly influenced by several environmental factors, such as light intensity, direction of the water currents (which in turn depend on spring-tides, thus on moon phases), temperature, and salinity.

It must be remarked that a decisive answer on the quantitative influence of light intensity and temperature, has not yet been given, seen the paucity of data available.
A future line of research is no doubt rearing of G.zaddachi in fresh-water, to which small quantities of certain ions have been added, in the first place $\mathrm{Ca}$ and $\mathrm{Mg}$. The relation between the temperature at the one hand, and the ionic composition of the medium at the other, especially its effect on the reproduction and on the osmoregulatory system, could be much more complex than it appears now at first sight.

Not yet solved either at this moment is the possible relation between the salinity and the number of eggs produced.

\section{RESUME}

1 - Les auteurs ont cherché à identifier des Gammarides juvéniles récoltés dans la zone de marées d'eau douce (voir point 6) de la Slack (France), 3 à $4 \mathrm{~km}$ en amont de l'estuaire. Ces spécimens juvéniles furent d'abord considérés (du point de vue de leur morphologie) comme appartenant à l'espèce Gammarus salinus.

2 - L'élevage de ces spécimens a montré qu'ils se développaient en adultes de Gammarus zaddachi. Ceci prouve que les critères morphologiques utilisés pour distinguer $G$. salinus et $G$. zaddachi ne peuvent être appliqués au matériel juvénile. Plusieurs critères morphologiques ont été considérés et testés. Il apparait qu'il n'y a pas de caractère-clé sûr à $100 \%$, c'est-à-dire qu'il est impossible d'identifier avec une certitude absolue tous les individus d'une population mixte de ces deux espèces.

3 - En même temps, la ressemblance entre G. zaddachi jeune et $G$. salinus adulte fournit un caractère morphologique qui permet, au cours de recherches sur un très grand nombre d'exemplaires, de distinguer rapidement les formes adultes et jeunes de G. zaddachi.

4 - Lors des recherches sur la reproduction et la migration de G. zaddachi, on a conçu et confectionné divers types de filets. Ils permettent de capturer les migrants anadromes aussi bien que catadromes. Leurs capacités se sont révélées équivalentes.

5 - L'activité de G. zaddachi montre une périodicité diurne; elle culmine durant la nuit. Ce comportement résulte dans une migration vers l'aval ("dérive"); elle atteint son maximum environ 2 à $3 \mathrm{~h}$. après le coucher du soleil, pour diminuer ensuite à mesure que la nuit s'avance; la "derive" s'arrête pratiquement au lever du soleil. On n'a pu constater aucune influence de l'intensité lumineuse nocturne (phase lunaire, nuages).

6 - Durant la période des grandes marées, la direction du courant se renverse sur tout le secteur de recherche. Sur la section de la rivière voisine de l'estuaire, ce revirement s'accompagne d'une augmentation rapide de la salinité. Plus en amont la salinité ne change pas : on trouve là une zone de marées d'eau douce.

7 - Toute l'année, une certaine partie de la population habitant un endroit donné (le soi-disant ..standing crop") migre en aval. Pendant les grandes marées d'équinoxe d'automne (et à un degré moindre à l'équinoxe de prin- temps) la migration se fait en masse vers l'amont; toutefois, cette migration n'a lieu que durant les nuits où le courant s'inverse sous l'influence d'une forte marée. Pratiquement ce ne sont que les individus juvéniles qui participent à cette migration en amont.

8 - Le maximum d'individus pris en un seul filet $(30 \times$ $50 \mathrm{~cm}$ ) et en une nuit fut de $1.500 \mathrm{G}$. zaddachi descendant le courant et de 6.000 remontant le courant; ceci correspondrait environ à 30.000 individus descendant le courant, et à 120.000 le remontant, pour une section de la rivière. Dans la Slack, aucune autre espèce de Gammaride ne manifeste de comportement migratoire.

9-Les expériences avec des individus marqués ont montré que les migrateurs vers l'amont couvrent des distances de 40 a $60 \mathrm{~m}$ en une nuit. Les migrateurs vers l'aval couvrent au moins $50 \mathrm{~m}$ et au plus $80 \mathrm{~m}$ en une seule nuit.

10 - Divers indices donnent à penser que les déplacements de G. zaddachi vers l'amont et vers l'aval ne sont pas purement accidentels, bien qu'il profite des courants pour migrer. Les individus qui se trouvent dans la phase (physiologique) de descendre la rivière, persévèrent dans ce sens en dépit du courant. Il en va de même des individus qui se trouvent en phase de remonter la rivière.

11 - Le cycle de reproduction de G. zaddachi s'accomplit sur une année. Les jeunes font leur apparition au printemps; ils parviennent à maturité à l'automne; on trouve les premières femelles ovigères en Décembre; le maximum de pontes se situe au début du printemps. Tous les adultes meurent après la période de reproduction.

12 - Le cycle de reproduction est lié au cycle des migrations. Les femelles qui participent à la migration vers l'aval, peuvent se reproduire avec succès si la température et la salinité sont favorables. Lorsque la température dépasse $7^{\circ} 5 \mathrm{C}$, il n'y a de reproduction que dans les parties mixohalines de la Slack. Quand la température baisse au dessous de $7^{\circ} 5 \mathrm{C}$, la ponte est également possible dans les secteurs limniques de la rivière.

Les jeunes passent l'été dans la zone de l'estuaire. A cette saison, G. zaddachi disparait d'une grande partie de l'aire de répartition, en amont de la rivière. Ce sont les jeunes, aidés par les courants des grandes marées, qui repeuplent la région limnique en automne; le cycle est ainsi bouclé. 


\section{REFERENCES}

Bassindale, R., 1942. The distribution of amphipods in the Severn estuary and Bristol Channel. J. anim. Ecol., 11: 131-144.

DEndy, J. S., 1944. The fate of animals in stream drift when carried into lakes. Ecol. Monogr., 14 (3): 333-357.

Ellior, J. M., 1967. Invertebrate drift in a Dartmore stream. Arch. Hydrobiol., 63 (2): 202-237.

HARkER, J. E., 1964. The physiology of diurnal rhythms. (Cambridge University Press).

Hultis, L., 1968. A method of trapping fresh water Amphipoda migrating upstream. Oikos, 19: 400-402.

Hynes, H. B. N., 1954. The ecology of Gammarus duebeni Lilljeborg and its occurrence in fresh water in western Britain. J. amin. Ecol., 23: 38-84.

JANSSON, B. O. \& Källander, C., 1968. On the diurnal activity of some littoral peracarid crustaceans in the Baltic Sea. J. exp. mar. Biol. Ecol., 2: 24-36.

Kinse, O., 1952. Zum Lebenszyklus von Gammarus duebeni Lilljeborg, nebst einigen Bemerkungen zur Biologie von Gammarus zaddachi Sexton ssp. zaddachi Spooner. Veröff. Inst. Meeresforsch. Bremerhaven, 1: 187-203.

— , 1953. Wird die Häutungsfolge der Amphipoden (Gammarus zaddachi zaddachi Sextion, G. zaddachi salinus Spooner, G. duebeni Lillj.) durch die lunäre Periodicität beeinflusst? Kieler Meeresforsch.. 9: 271-279.

—, 1954. Die Gammarus-Arten der Kieler Bucht. . . . Zool. Jahrb. (Syst.), 82: 405-424.

-, 1960a. Gammarus salinus - Einige Daten über dem Umwelteinfluss auf Wachstum, Häutungsfolge, Herzfrequenz und Eientwicklungsdauer. Crustaceana, I (3): 208-217.

- ,1960b. Growth, moulting frequency, heart beat, number of eggs and incubation time in Gammarus zaddachi exposed to different environments. Crustaceana, 2 (1): 26-36.

,- 1961. Moulting frequency of mature Gammarus zaddachi. Correction. Crustaceana, 2 (2): 171.

LehmanN, U., 1967. Drift und Populationsdynamik von Gammarus pulex fossarum Koch. Z. Morph. Ökol. Tiere, 60: 227-274.

McLAy, C. L., 1968. A study of drift in the Kakanui river, New Zealand. Aust. J. mar. Freshwat. Res., 19 (2): 139149.

MinckLeY, W. L., 1964. Upstream movements of Gammarus (Amphipoda) in Doe Run, Meade County, Kentucki. Ecology, 45 (1): 195-197.

MülLER, K., 1954a. Investigations on the organic drift in North Swedish streams. Rep. Inst. Freshwat. Res. Drottningholm, 35: 133-148.

-, 1954b. Die Drift in fliessenden Gewässern. Arch. Hydrobiol., 49: 539-545.

- ,1963a. Temperatur und Tagesperiodik der "Organischen Drift" von Gammarus pulex. Naturwiss., 50: 410-411.

- , 1963b. Diurnal rhythm in "organic drift" of Gammarus pulex. Nature (London), 198: 806-807.

-, 1966a. Zur Periodik von Gammarus pulex. Oikos, 17: 207-211.
- ,1966b. Die Tagesperiodik von Flieswasserorganismen. Z. Morph. Ökol. Tiere, 46: 93-142.

NEEDHAM, P. R., 1928. A net for the capture of stream drift organisms. Ecology, 9: 339-342.

REID, D. M., 1943. Gammarus sarsi, sp.n. (Crustacea, Amphipoda). Ann. Mag. nat. Hist., (11) 10: 281-285.

-, 1945. Gammarus ochlos (nom. nov.), Crustacea, Amphipoda. Ann. Mag. nat. Hist., (11) 12: 637-638.

SegerstrÅle, S. G., 1947. New observations on the distribution and morphology of the amphipod Gammarus zaddachi Sexton, with notes on related species. J. mar. biol. Ass. U.K., 27: 219-244.

SExton, E. W., 1912. Some brackish-water Amphipoda from the mouths of the Weser and the Elbe, and from the Baltic. Proc. zool. Soc. London, 1912: 656-665.

-, 1913. On a collection of Gammarus from the Königsberg Museum. Schr. Königsberg physik. Ges., 54: 90-94.

,- 1924 . The moulting and growth-stages of Gammarus, with description of the normals and intersexes of $G$. chevreuxi. J. mar. biol. Ass. U.K., 13 (2): 340-401.

-, 1928. On the rearing and breeding of Gammarus in laboratory conditions. J. mar. biol. Ass. U.K., 15 (1): 33-55.

- , 1942. The relation of Gammarus zaddachi Sexton to some other species of Gammarus ocurring in fresh, estuarine and marine waters. J. mar. biol. Ass. U.K., 25: 575-606.

Spooner, G. M., 1947. The distribution of Gammarus species in estuaries, 1. J. mar. biol. Ass. U.K., 27: 1-52.

STock, J. H. \& KaNT, P., 1966. What is Gammarus campylops of Sars, 1894? Bull. zool. Mus. Univ. Amsterdam. 1 (2): 7-18.

Stock, J. H., Nijssen, H. \& Kant, P., 1966. La répartition écologique des Amphipodes de la famille des Gammaridae dans la Slack et son estuaire. Bull. zool. Mus. Univ. Amsterdam, 1 (3): 19-30.

TANaka, H., 1960. On the daily change of drifting of benthic animals in streams, especially on the types of daily change observed in taxonomix groups of insects. Bull. Freshwat. Fish. Res. Lab. Tokyo, 9: 13-24.

VERwEY, J., 1966. The role of some external factors in the vertical migration of marine animals. Netherl. J. Sea Res., 3 (2): 245-266.

Waters, T. F., 1961. Standing crop and drift of stream bottom organisms. Ecology, 42: 532-537.

-, 1962a. A method to estimate the production rate of a stream bottom invertebrate. Trans. Amer. Fish. Soc., 91: 243-250.

-, 1962b. Diurnal periodicity in the drift of stream invertebrates. Ecology, 43 (2): 316-320.

,- 1964 . Recolonization of denuded stream bottom areas by drift. Trans. Amer. Fish. Soc., 93: 311-315.

,- 1965 . Interpretation of invertebrate drift in streams. Ecology, 46 (3): 327-334.

Wijvekate, M. L., 1966. Verklarende statistiek (8th ed.). Aula, 39. (Utrecht). 